\title{
Platforms Exploited for SARS-CoV-2 Vaccine Development
}

\author{
Shilu Mathew ${ }^{1,+}$, Muhammed Faheem ${ }^{2,+}$, Neeraja A. Hassain ${ }^{3}{ }^{(\mathbb{C}}$, Fatiha M. Benslimane ${ }^{1}(\mathbb{D}$, \\ Asmaa A. Al Thani ${ }^{1,4}$, Hassan Zaraket ${ }^{5,6, \ddagger(D)}$ and Hadi M. Yassine ${ }^{1,4, *, \ddagger(D)}$ \\ 1 Biomedical Research Center, Qatar University, Doha 2173, Qatar; shilu.mathew@qu.edu.qa (S.M.); \\ fatiha@qu.edu.qa (F.M.B.); aaja@qu.edu.qa (A.A.A.T.) \\ 2 Genetics \& Genome Biology Program, The Hospital for Sick Children, Toronto, ON M5G 0A4, Canada; \\ a08faheem@gmail.com \\ 3 Department of Biotechnology, Jamal Mohamed College, Tamil Nadu 620020, India; \\ neeraja.anandamyle@gmail.com \\ 4 Department of Public Health, College of Health Sciences, Qatar University, Doha 2173, Qatar \\ 5 Department of Experimental Pathology, Immunology, and Microbiology, Faculty of Medicine, \\ American University of Beirut, Beirut 11-0236, Lebanon; hz34@aub.edu.lb \\ 6 Center for Infectious Diseases Research, American University of Beirut, Beirut 11-0236, Lebanon \\ * Correspondence: hyassine@qu.edu.qa \\ + These authors contributed equally to this work. \\ $\ddagger \quad$ These authors contributed equally to this work.
}

Citation: Mathew, S.; Faheem, M.; Hassain, N.A.; Benslimane, F.M.; Al Thani, A.A.; Zaraket, H.; Yassine, H.M. Platforms Exploited for SARS-CoV-2 Vaccine Development. Vaccines 2021, 9, 11. https://doi.org/ $10.3390 /$ vaccines 9010011

Received: 4 October 2020 Accepted: 4 December 2020 Published: 25 December 2020

Publisher's Note: MDPI stays neutral with regard to jurisdictional clai$\mathrm{ms}$ in published maps and institutional affiliations.

Copyright: (C) 2020 by the authors. Licensee MDPI, Basel, Switzerland. This article is an open access article distributed under the terms and conditions of the Creative Commons Attribution (CC BY) license (https:// creativecommons.org/licenses/by/ $4.0 /)$.

\begin{abstract}
The novel severe acute respiratory syndrome coronavirus 2 (SARS-CoV-2) is the only zoonotic-origin coronavirus $(\mathrm{CoV})$ that has reached the pandemic stage. The virus uses its spike (S) glycoprotein to attach to the host cells and initiate a cascade of events that leads to infection. It has sternly affected public health, economy, education, and social behavior around the world. Several scientific and medical communities have mounted concerted efforts to limit this pandemic and the subsequent wave of viral spread by developing preventative and potential vaccines. So far, no medicine or vaccine has been approved to prevent or treat coronavirus disease 2019 (COVID-19). This review describes the latest advances in the development of SARS-CoV-2 vaccines for humans, mainly focusing on the lead candidates in clinical trials. Moreover, we seek to provide both the advantages and the disadvantages of the leading platforms used in current vaccine development, based on past vaccine delivery efforts for non-SARS CoV-2 infections. We also highlight the population groups who should receive a vaccine against COVID-19 in a timely manner to eradicate the pandemic rapidly.
\end{abstract}

Keywords: SARS-CoV-2; Covid-19; vaccines; clinical trials; vaccine platforms

\section{Introduction}

Severe acute respiratory syndrome coronavirus 2 (SARS-CoV-2) is the causative agent of coronavirus disease 2019 (COVID-19) that emerged in Wuhan, China, in December 2019 [1,2]. Infection with SARS-CoV-2 is asymptomatic or results in mild flu-like symptoms in about $80 \%$ of the patients. However, people aged over 70 have long-term health conditions such as asthma or diabetes; people with a weakened immune system may suffer from severe illnesses like pneumonia and acute respiratory failure. COVID-19 could also be fatal for people with comorbidities [2-4]. To enter the host cell, coronavirus (CoV) utilizes its transmembrane spike (S) glycoprotein. First, the virus binds to a cell surface receptor, subsequently enters endosomes, and eventually fuses with the lysosomal membranes [5]. The S protein exists as a trimer with two domains, the S1 head and the S2 stalk on a mature virus. SARS-CoV-2 S1 subunit contains the receptor-binding domain (RBD), which primarily identifies angiotensin-converting enzyme-2 (ACE-2) as its receptor [6]. The RBD continuously shifts between a standing position to bind with the receptor and a lying-down position for immune evasion [7]. Furthermore, for membrane fusion, the SARS-CoV-2 
spike requires to be proteolytically cleaved at the S1/S2 boundary in such a way that S1 dissociates, and S2 undergoes a structural change [8]. These features of SARS-CoV-2 entry contribute to its rapid spread, severe symptoms, and high fatality rates of infected patients [9,10]. As of 8 September 2020, SARS-CoV-2 had infected over 28 million people in 216 countries/territories, causing over 906 thousand fatalities [11]. The virus has a very high infection rate, making it more contagious than other $\mathrm{CoV}$, including the severe acute respiratory syndrome coronavirus 1 (SARS-CoV-1) and the Middle East respiratory syndrome coronavirus (MERS-CoV) [12,13]. Concerned both by the alarming spread and the severity levels, the World Health Organization (WHO) declared COVID-19 a pandemic by 11 March 2020 [14]. Despite continuous efforts to contain the pandemic, there is still no vaccine nor an approved therapeutic cure for COVID-19. The current treatments rely on existing antiviral repurposed drugs combined with adjunct immune therapy, such as corticosteroids treatment [15]. Hence, the development of SARS-CoV-2 effective prophylactics and vaccines remains crucial [16-18]. With this background, many institutions and pharmaceutical companies have stepped forward to develop an effective and safe vaccine by the end of December 2021. This ambitious plan initially focused on 125 potential vaccine candidates but it has narrowed to 34 vaccine candidates (as of 8 September 2020) currently in clinical evaluation [19]. Given this, we describe the different approaches, proposed mechanisms, and status of the leading candidate vaccines developed against COVID-19 now in clinical trials.

\section{Multiple Vaccine Platforms and Vaccines Currently in Clinical Evaluation}

To increase the chances of safe and effective vaccines for COVID-19, the WHO has facilitated the collaboration between many institutes and research communities across the world and has accelerated its efforts on a greater scale to evaluate different platforms for candidate vaccines [20]. The platforms currently exploited for SARS-CoV-2 vaccine are depicted in Figure 1A. As of September, the following vaccine platforms are in the final Phase II and Phase III of clinical trials [19]. Table 1 presents the current vaccine candidates in clinical evaluation, proposed by the WHO (8 September 2020). 
Table 1. List of candidate vaccines for severe acute respiratory syndrome coronavirus 2 (SARS-CoV-2) under clinical evaluation.

\begin{tabular}{|c|c|c|c|c|c|c|c|}
\hline $\begin{array}{l}\text { Vaccine } \\
\text { Platform }\end{array}$ & $\begin{array}{c}\text { COVID-19 Vaccine } \\
\text { Developer/Manufacturer }\end{array}$ & $\begin{array}{l}\text { Type of Candidate } \\
\text { Vaccine }\end{array}$ & Dosage & $\begin{array}{l}\text { Number of Shots } \\
\text { (with Time Interval) }\end{array}$ & Primary Study Adverse Side Effects & $\begin{array}{l}\text { Number of } \\
\text { Subjects }\end{array}$ & References \\
\hline \multirow{4}{*}{$\begin{array}{l}\text { Non- } \\
\text { replicating } \\
\text { viral } \\
\text { vector }\end{array}$} & $\begin{array}{c}\text { University of } \\
\text { Oxford/AstraZeneca } \\
\text { (August 2020-October 2022) }\end{array}$ & $\begin{array}{l}\text { ChAdOx1-S } \\
\text { NCT04516746, } \\
\text { NCT04540393 }\end{array}$ & $\begin{array}{l}5 \times 10^{10} \mathrm{vp}(\text { nominal } \\
\left.\quad \pm 1.5 \times 10^{10} \mathrm{vp}\right)\end{array}$ & 2 (0, 28 days); IM & $\begin{array}{l}\text { Phase } 3 \\
\text { - } \quad \text { Higher efficacy regimen used a } \\
\text { halved first dose and standard } \\
\text { second dose }\end{array}$ & $\begin{array}{l}\text { Humans } \\
(40,000 \\
\text { participants })\end{array}$ & \multirow{4}{*}[19,21-25]{} \\
\hline & $\begin{array}{l}\text { CanSino Biological Inc. / Beijing } \\
\text { Institute of Biotechnology } \\
\text { (September 2020-July 2021/ } \\
\text { September 2020-January 2022) }\end{array}$ & $\begin{array}{c}\text { Adenovirus type } 5 \\
\text { vector } \\
\text { NCT04540419/ } \\
\text { NCT04526990 }\end{array}$ & $5 \times 10^{10} \mathrm{vp} / 0.5 \mathrm{~mL}$ & 1; IM & $\begin{array}{l}\text { Phase } 3 \\
\text { - } \quad \text { Induced significant immune } \\
\quad \text { response in phase } 2 \text { trial }\end{array}$ & $\begin{array}{c}\text { Humans } \\
(40,000 / 500 \\
\text { participants })\end{array}$ & \\
\hline & $\begin{array}{l}\text { Gamaleya Research Institute } \\
\text { (September 2020-May 2021) }\end{array}$ & $\begin{array}{l}\text { Adeno-based } \\
\text { (rAd26-S + rAd5-S) } \\
\text { NCT04530396 }\end{array}$ & $\begin{array}{c}\text { Gam-COVID-Vac } \\
0.5 \mathrm{~mL}\end{array}$ & $\stackrel{2}{2}(0,21$ days $) ; \mathrm{IM}$ & $\begin{array}{l}\text { Phase } 3 \\
\text { - } \quad \text { Induced antibody responses } \\
\quad \text { with no serious adverse events }\end{array}$ & $\begin{array}{l}\text { Humans } \\
(40,000 \\
\text { participants })\end{array}$ & \\
\hline & $\begin{array}{l}\text { ReiThera/LEUKOCARE/ } \\
\text { Univercells } \\
\text { (August 2020-July 2021) }\end{array}$ & $\begin{array}{l}\text { Replication defective } \\
\text { Simian Adenovirus } \\
\text { (GRAd) encoding S } \\
\text { NCT04528641 }\end{array}$ & $\begin{array}{l}5 \times 10^{10} \mathrm{vp} \\
1 \times 10^{11} \mathrm{vp} \\
\text { or } 2 \times 10^{11} \mathrm{vp}\end{array}$ & 1; IM & $\begin{array}{l}\text { Phase } 1 \\
\text { NA }\end{array}$ & $\begin{array}{l}\text { Humans } \\
\text { (90 partici- } \\
\text { pants) }\end{array}$ & \\
\hline \multirow[b]{2}{*}{ Inactivated } & $\begin{array}{c}\text { Sinovac } \\
\text { (July 2020-October 2021) }\end{array}$ & $\begin{array}{c}\text { Inactivated } \\
\text { NCT04456595 }\end{array}$ & $3 \mu \mathrm{g} / 0.5 \mathrm{~mL}$ & $\stackrel{2}{2}(0,14$ days $) ; \mathrm{IM}$ & $\begin{array}{l}\text { Phase } 3 \\
\text { NA }\end{array}$ & $\begin{array}{c}\text { Humans } \\
(13,060 \\
\text { participants })\end{array}$ & \multirow[b]{2}{*}[19,26-28]{} \\
\hline & $\begin{array}{l}\text { Wuhan Institute of Biological } \\
\text { Products/Sinopharm } \\
\text { (April 2020-November 2021) }\end{array}$ & $\begin{array}{c}\text { Inactivated } \\
\text { ChiCTR2000031809 }\end{array}$ & $\begin{array}{c}2.5 \mu \mathrm{g}, 5 \mu \mathrm{g} \text { and } \\
10 \mu \mathrm{g} / \text { dose }\end{array}$ & $\begin{array}{c}\mathbf{2} \\
(0,14 \text { or } 0,21 \text { days }) \\
\text { IM }\end{array}$ & $\begin{array}{l}\text { Phase } 1 / 2 \\
\text { - } \quad \text { Adverse reaction reported } \\
\quad \text { within } 7 \text { days of injection. }\end{array}$ & $\begin{array}{l}\text { Humans } \\
\text { (340 partici- } \\
\text { pants) }\end{array}$ & \\
\hline
\end{tabular}


Table 1. Cont

\begin{tabular}{|c|c|c|c|c|c|c|c|}
\hline $\begin{array}{l}\text { Vaccine } \\
\text { Platform }\end{array}$ & $\begin{array}{c}\text { COVID-19 Vaccine } \\
\text { Developer/Manufacturer }\end{array}$ & $\begin{array}{l}\text { Type of Candidate } \\
\text { Vaccine }\end{array}$ & Dosage & $\begin{array}{l}\text { Number of Shots } \\
\text { (with Time Interval) }\end{array}$ & Primary Study Adverse Side Effects & $\begin{array}{l}\text { Number of } \\
\text { Subjects }\end{array}$ & References \\
\hline & $\begin{array}{l}\text { Beijing Institute of Biological } \\
\text { Products / Sinopharm } \\
\text { (July 2020-July 2021) }\end{array}$ & $\begin{array}{c}\text { Inactivated } \\
\text { ChiCTR2000032459 }\end{array}$ & $2 \mu \mathrm{g}, 4 \mu \mathrm{g}$ or $8 \mu \mathrm{g}$ & $\begin{array}{l}2 \\
(0,14 \text { or } 0,21 \text { days }) \\
\text { IM }\end{array}$ & $\begin{array}{l}\text { Phase } 1 / 2 \\
\text { - Adverse reaction was reported } \\
\quad \text { within } 7 \text { days of the first } \\
\text { inoculation in } 49 \% \text { of subjects. } \\
\text { Grade } 3 \text { fever was reported but was } \\
\text { self-limited. }\end{array}$ & $\begin{array}{l}\text { Humans } \\
(1192 \\
\text { participants })\end{array}$ & \\
\hline & $\begin{array}{l}\text { Research Institute for Biological } \\
\text { safety problems, Rep of } \\
\text { Kazakhstan } \\
\text { (September 2020-December } \\
\text { 2020) }\end{array}$ & $\begin{array}{c}\text { Inactivated } \\
\text { NCT04530357 }\end{array}$ & $\begin{array}{c}0.5 \mathrm{~mL} \text { of } \\
\text { QazCovid-in }{ }^{\circledR}\end{array}$ & $\stackrel{2}{2}(0,21$ days $) ; \mathrm{IM}$ & $\begin{array}{l}\text { Phase } 1 / 2 \\
\text { - } \quad \text { Occurrence of serious adverse } \\
\text { events after vaccination }\end{array}$ & $\begin{array}{l}\text { Humans } \\
\text { (244 partici- } \\
\text { pants) }\end{array}$ & \\
\hline & $\begin{array}{c}\text { Bharat Biotech } \\
\text { (November 2020-February 2022) }\end{array}$ & $\begin{array}{l}\text { Whole-Virion } \\
\text { inactivated } \\
\text { NCT04473690 }\end{array}$ & KBP-COVID-19, & $\frac{2}{(0,14 \text { days }) ; \mathrm{IM}}$ & $\begin{array}{l}\text { Phase } 1 / 2 \\
\text { - } \quad \text { Occurrence of immediate } \\
\text { adverse effects after vaccination }\end{array}$ & $\begin{array}{l}\text { Humans } \\
\text { (180 partici- } \\
\text { pants) }\end{array}$ & \\
\hline \multirow[t]{2}{*}{ RNA } & $\begin{array}{c}\text { Moderna/NIAID } \\
\text { (July 2020-October 2022) }\end{array}$ & $\begin{array}{l}\text { LNP-encapsulated } \\
\text { mRNA } \\
\text { NCT04470427 }\end{array}$ & $100 \mu \mathrm{g} /$ dose & $\stackrel{2}{2}(0,28$ days $) ; \mathrm{IM}$ & $\begin{array}{l}\text { Phase } 3 \\
\text { - } \quad \text { M-RNA-1273 met its primary } \\
\text { efficacy endpoint in the first } \\
\text { interim analysis with efficacy of } \\
94.5 \%\end{array}$ & $\begin{array}{l}\text { Humans } \\
(30,000 \\
\text { participants })\end{array}$ & \multirow[t]{2}{*}[19,29-32]{} \\
\hline & $\begin{array}{c}\text { BioNTech/Fosum } \\
\text { Pharma/Pfizer } \\
\text { (April 2020-December 2022) }\end{array}$ & $\begin{array}{l}\text { LNP-mRNAs } \\
\text { NCT04368728 }\end{array}$ & $10 \mu \mathrm{g} /$ dose, & $\stackrel{2}{2}(0,28$ days $) ; \mathrm{IM}$ & $\begin{array}{l}\text { Phase } 2 / 3 \\
\text { - } \quad \text { Local reactions }\end{array}$ & $\begin{array}{c}\text { Humans } \\
(43,998 \\
\text { participants })\end{array}$ & \\
\hline
\end{tabular}


Table 1. Cont

\begin{tabular}{|c|c|c|c|c|c|c|c|}
\hline $\begin{array}{l}\text { Vaccine } \\
\text { Platform }\end{array}$ & $\begin{array}{c}\text { COVID-19 Vaccine } \\
\text { Developer/Manufacturer }\end{array}$ & $\begin{array}{l}\text { Type of Candidate } \\
\text { Vaccine }\end{array}$ & Dosage & $\begin{array}{l}\text { Number of Shots } \\
\text { (with Time Interval) }\end{array}$ & Primary Study Adverse Side Effects & $\begin{array}{l}\text { Number of } \\
\text { Subjects }\end{array}$ & References \\
\hline & $\begin{array}{c}\text { Curevac } \\
\text { (September 2020-November } \\
\text { 2021) }\end{array}$ & $\begin{array}{c}\text { mRNA } \\
\text { NCT04515147 }\end{array}$ & $4 \mu \mathrm{g} /$ dose & $\begin{array}{c}2 \\
(0,28 \text { days }) ; \mathrm{IM}\end{array}$ & $\begin{array}{l}\text { Phase } 2 \\
\text { NA }\end{array}$ & $\begin{array}{l}\text { Humans } \\
\text { (691 partici- } \\
\text { pants) }\end{array}$ & \\
\hline & Arcturus/Duke-NUS & $\begin{array}{c}\text { mRNA } \\
\text { NCT04480957 }\end{array}$ & $0.5 \mathrm{~mL}$ & $4 ; \mathrm{IM}$ & $\begin{array}{l}\text { Phase } 1 / 2 \\
\begin{array}{l}\text { - Severe adverse effects after } 7 \\
\text { days of vaccination }\end{array}\end{array}$ & $\begin{array}{l}\text { Humans } \\
\text { (92 partici- } \\
\text { pants) }\end{array}$ & \\
\hline & $\begin{array}{l}\text { Imperial College London } \\
\text { (April 2020-June 2021) }\end{array}$ & $\begin{array}{l}\text { LNP-nCoVsaRNA } \\
\text { ISRCTN17072692 }\end{array}$ & $0.1 \mu \mathrm{g} /$ dose & 2; IM & $\begin{array}{l}\text { Phase } 1 \\
\text { NA }\end{array}$ & Humans & \\
\hline & $\begin{array}{c}\text { People's Liberation Army (PLA) } \\
\text { Academy of Military } \\
\text { Sciences/Walvax Biotech. } \\
\text { (June 2020-December 2021) }\end{array}$ & $\begin{array}{c}\text { mRNA } \\
\text { ChiCTR2000034112 }\end{array}$ & $\begin{array}{l}5 \times 10^{10}, 1 \times 10^{11} \\
\text { and } 1.5 \times 10^{11} \mathrm{vp}\end{array}$ & $\begin{array}{c}2(0,14 \text { or } 0,28 \text { days }) \\
\text { IM }\end{array}$ & $\begin{array}{l}\text { Phase } 1 \\
\text { NA }\end{array}$ & $\begin{array}{l}\text { Humans (168 } \\
\text { participants) }\end{array}$ & \\
\hline \multirow{4}{*}{ DNA } & $\begin{array}{c}\text { Inovio } \\
\text { Pharmaceuticals/International } \\
\text { Vaccine Institute } \\
\text { (July 2020-February 2022) }\end{array}$ & $\begin{array}{l}\text { DNA plasmid } \\
\text { vaccine with } \\
\text { electroporation } \\
\text { NCT04447781 }\end{array}$ & $\begin{array}{l}\text { INO-4800 } 1 \mathrm{mg} \text { or } \\
2 \mathrm{mg} / \text { dose using } \\
\text { CELECTRA }^{\circledR} 2000,\end{array}$ & $\begin{array}{c}2 \\
(0,28 \text { days }) ; \mathrm{ID}\end{array}$ & $\begin{array}{l}\text { Phase } 1 / 2 \\
\text { NA }\end{array}$ & $\begin{array}{l}\text { Humans (160 } \\
\text { participants) }\end{array}$ & \multirow{4}{*}[19,29]{} \\
\hline & $\begin{array}{c}\text { Osaka } \\
\text { University / AnGes/Takara Bio } \\
\text { (June 2020-July 2021) }\end{array}$ & $\begin{array}{l}\text { DNA plasmid } \\
\text { vaccine + Adjuvant } \\
\text { NCT04463472 }\end{array}$ & $1 \mathrm{mg}$ or $2 \mathrm{mg} /$ dose & 2 (0, 14 days); IM & $\begin{array}{l}\text { Phase } 1 / 2 \\
\text { - Incidence of treatment-serious } \\
\text { adverse effects }\end{array}$ & $\begin{array}{l}\text { Humans } \\
\text { (30 partici- } \\
\text { pants) }\end{array}$ & \\
\hline & $\begin{array}{l}\text { Cadila Healthcare Limited } \\
\text { (July 2020-July 2021) }\end{array}$ & $\begin{array}{l}\text { DNA plasmid } \\
\text { vaccine } \\
\text { CTRI/2020/07/02635 }\end{array}$ & $1 \mathrm{mg} /$ dose & $\begin{array}{c}3 \\
(0,28,56 \text { days }) ; \mathrm{ID}\end{array}$ & $\begin{array}{l}\text { Phase } 1 / 2 \\
\text { NA }\end{array}$ & $\begin{array}{l}\text { Humans } \\
\text { (1048 partici- } \\
\text { pants) }\end{array}$ & \\
\hline & $\begin{array}{l}\text { Genexine Consortium } \\
\text { (June 2020-June 2022) }\end{array}$ & $\begin{array}{l}\text { DNA vaccine (GX-19) } \\
\text { NCT0445389 }\end{array}$ & GX-19, & $\begin{array}{c}2 \\
(0,28 \text { days }) ; \mathrm{IM}\end{array}$ & $\begin{array}{l}\text { Phase } 1 / 2 \\
\text { - Incidence of solicited, } \\
\text { and serious adverse events }\end{array}$ & $\begin{array}{l}\text { Humans (210 } \\
\text { participants) }\end{array}$ & \\
\hline
\end{tabular}


Table 1. Cont

\begin{tabular}{|c|c|c|c|c|c|c|c|}
\hline $\begin{array}{l}\text { Vaccine } \\
\text { Platform }\end{array}$ & $\begin{array}{c}\text { COVID-19 Vaccine } \\
\text { Developer/Manufacturer }\end{array}$ & $\begin{array}{l}\text { Type of Candidate } \\
\text { Vaccine }\end{array}$ & Dosage & $\begin{array}{l}\text { Number of Shots } \\
\text { (with Time Interval) }\end{array}$ & Primary Study Adverse Side Effects & $\begin{array}{l}\text { Number of } \\
\text { Subjects }\end{array}$ & References \\
\hline \multirow{5}{*}{$\begin{array}{l}\text { Protein } \\
\text { subunit }\end{array}$} & $\begin{array}{c}\text { Novavax } \\
\text { (August 2020-November 2021) }\end{array}$ & $\begin{array}{c}\text { Full-length } \\
\text { recombinant SARS } \\
\text { CoV-2 glycoprotein } \\
\text { nanoparticle vaccine } \\
\text { adjuvanted with } \\
\text { Matrix M } \\
\text { NCT04533399 }\end{array}$ & $\begin{array}{l}\text { SARS-CoV-2rS- } 5 \mu \mathrm{g}+ \\
50 \mu \mathrm{g} \text { Matrix-M1 } \\
\text { adjuvant } \\
\text { (co-formulated) }\end{array}$ & $\stackrel{2}{2}$ (0, 21 days); IM; & $\begin{array}{l}\text { Phase } 2 b \\
\text { NA }\end{array}$ & $\begin{array}{l}\text { Humans } \\
\text { (4400 partici- } \\
\text { pants) }\end{array}$ & \multirow{5}{*}[19,33-35]{} \\
\hline & $\begin{array}{c}\text { Kentucky Bioprocessing, Inc } \\
\text { (November 2020-February 2022) }\end{array}$ & $\begin{array}{l}\text { RBD-based } \\
\text { NCT04473690 }\end{array}$ & $\begin{array}{l}\text { Low and high doses } \\
\text { of KBP-201 } \\
\text { COVID-19 }\end{array}$ & $\stackrel{2}{2}(0,21$ days $) ; \mathrm{IM}$ & $\begin{array}{l}\text { Phase } 1 / 2 \\
\text { - } \quad \text { Solicited administration-site } \\
\text { reactions after } 7 \text { days of } \\
\text { vaccination } \\
\text { - } \quad \text { Occurrence of adverse events }\end{array}$ & $\begin{array}{l}\text { Humans } \\
\text { (180 partici- } \\
\text { pants) }\end{array}$ & \\
\hline & $\begin{array}{c}\text { Sanofi Pasteur/GSK } \\
\text { (September 2020-October 2021) }\end{array}$ & $\begin{array}{l}\text { S protein } \\
\text { (baculovirus } \\
\text { production) } \\
\text { NCT04537208 }\end{array}$ & $\begin{array}{l}\text { Formulation not } \\
\text { defined }\end{array}$ & $\stackrel{2}{2}(0,21$ days $) ; \mathrm{IM}$ & $\begin{array}{l}\text { Phase } 1 / 2 \\
\text { NA }\end{array}$ & $\begin{array}{l}\text { Humans (440 } \\
\text { participants) }\end{array}$ & \\
\hline & $\begin{array}{l}\text { Clover Biopharmaceuticals } \\
\text { Inc./GSk/Dynavax } \\
\text { June 2020-March 2021) }\end{array}$ & $\begin{array}{l}\text { Native like Trimeric } \\
\text { subunit Spike Protein } \\
\text { vaccine } \\
\text { NCT044405908 }\end{array}$ & $3 \mu \mathrm{g} /$ dose & 2 (0, 21 days); IM & $\begin{array}{l}\text { Phase } 1 \\
\text { - Incidence of solicited adverse } \\
\text { events after } 7 \text { days of vaccination } \\
\text { - Incidence of serious adverse } \\
\text { events }\end{array}$ & $\begin{array}{l}\text { Humans } \\
\text { (150 partici- } \\
\text { pants) }\end{array}$ & \\
\hline & $\begin{array}{l}\text { Vaxine Pty Ltd./Medytox } \\
\text { (June 2020-July 2020) }\end{array}$ & $\begin{array}{l}\text { Recombinant spike } \\
\text { protein with } \\
\text { Advax }{ }^{\mathrm{TM}} \text { adjuvant } \\
\text { NCT04453852 }\end{array}$ & $\begin{array}{l}\text { S antigen } 25 \mu g+ \\
15 \text { mg Advax-2 } \\
\text { adjuvant/dose }\end{array}$ & 1; IM & $\begin{array}{l}\text { Phase } 1 \\
\text { - } \quad \text { Incidence of adverse events after } \\
7 \text { days of vaccination }\end{array}$ & $\begin{array}{l}\text { Humans (40 } \\
\text { participants) }\end{array}$ & \\
\hline
\end{tabular}


Table 1. Cont

\begin{tabular}{|c|c|c|c|c|c|c|c|}
\hline $\begin{array}{l}\text { Vaccine } \\
\text { Platform }\end{array}$ & $\begin{array}{c}\text { COVID-19 Vaccine } \\
\text { Developer/Manufacturer }\end{array}$ & $\begin{array}{l}\text { Type of Candidate } \\
\text { Vaccine }\end{array}$ & Dosage & $\begin{array}{l}\text { Number of Shots } \\
\text { (with Time Interval) }\end{array}$ & Primary Study Adverse Side Effects & $\begin{array}{l}\text { Number of } \\
\text { Subjects }\end{array}$ & References \\
\hline & $\begin{array}{c}\text { University of } \\
\text { Queensland/CSL/Seqirus } \\
\text { (July 2020-July 2021) }\end{array}$ & $\begin{array}{c}\text { Molecular clamp } \\
\text { stabilized Spike } \\
\text { protein with MF59 } \\
\text { adjuvant } \\
\text { ACTRN1262000067493 }\end{array}$ & $\begin{array}{c}5 \mathrm{mcg}, 15 \mathrm{mcg}, \\
\text { and } 45 \mathrm{mcg} / 0.5 \mathrm{~mL}\end{array}$ & $\begin{array}{c}2 \\
(0,28 \text { days }) ; \mathrm{IM}\end{array}$ & $\begin{array}{l}\text { Phase } 1 \\
\text { NA }\end{array}$ & $\begin{array}{l}\text { Humans } \\
\text { (120 partici- } \\
\text { pants) }\end{array}$ & \\
\hline & $\begin{array}{l}\text { Medigen Vaccine Biologics } \\
\text { Corporation/NIAID } \\
\text { (October 2020-June 2021) }\end{array}$ & $\begin{array}{c}\text { S-2P protein }+ \text { CpG } \\
1018 \\
\text { NCT04487210 }\end{array}$ & MVC-COV1901 & $2(0,28$ days $) ; \mathrm{IM}$ & $\begin{array}{l}\text { Phase } 1 \\
\text { NA }\end{array}$ & $\begin{array}{l}\text { Humans } \\
\text { (45 partici- } \\
\text { pants) }\end{array}$ & \\
\hline & $\begin{array}{l}\text { Instituto Finlay de Vancunas, } \\
\text { Cuba } \\
\text { (August 2020-January 2021) }\end{array}$ & $\begin{array}{l}\text { RBD + Adjuvant } \\
\text { IFV /CR/06 }\end{array}$ & Not specified & $\begin{array}{c}2 \\
(0,28 \text { days }) ; \mathrm{IM}\end{array}$ & $\begin{array}{l}\text { Phase } 1 \\
\text { - } \quad \text { Serious adverse events } \\
\quad \text { measurement, daily after each dose }\end{array}$ & Humans & \\
\hline & $\begin{array}{l}\text { FBRI SRC VECTOR, } \\
\text { Rospotrebnadzor } \\
\text { July 2020-October } 2020\end{array}$ & $\begin{array}{l}\text { RBD + Adjuvant } \\
\text { NCT04527575 }\end{array}$ & $\begin{array}{l}\text { EpiVacCorona } \\
0.5 \mathrm{~mL} / \text { dose }\end{array}$ & $\begin{array}{c}2 \\
(0,28 \text { days }) ; \mathrm{IM}\end{array}$ & $\begin{array}{l}\text { Phase } 1 \\
\text { NA }\end{array}$ & $\begin{array}{l}\text { Humans } \\
\text { (100 participants- } \\
\text { Active, not } \\
\text { recruiting) }\end{array}$ & \\
\hline & $\begin{array}{l}\text { West China Hospital, Sichuan } \\
\text { University } \\
\text { (October 2020-October2021) }\end{array}$ & $\begin{array}{c}\text { Peptide } \\
\text { ChiCTR2000037518 }\end{array}$ & $\begin{array}{c}20 \mu \mathrm{g} \text { and } \\
40 \mu \mathrm{g} / 0.5 \mathrm{~mL}\end{array}$ & $\begin{array}{c}2 \\
(0,21 \text { days }) ; \mathrm{IM}\end{array}$ & $\begin{array}{l}\text { Phase } 1 \\
\text { NA }\end{array}$ & $\begin{array}{l}\text { Humans }(120 \\
\text { participants- } \\
\text { Active, not } \\
\text { recruiting)) }\end{array}$ & \\
\hline $\begin{array}{l}\text { Others } \\
\text { (replicating } \\
\text { viral } \\
\text { vector) }\end{array}$ & $\begin{array}{c}\text { Institute Pasteur/Themis/Univ. } \\
\text { of Pittsburg CVR/Merck } \\
\text { Sharp \& Dohme } \\
\text { (August 2020-October2021) }\end{array}$ & $\begin{array}{l}\text { Measles-vector based } \\
\text { NCT04497298 }\end{array}$ & TMV-083 & $\begin{array}{c}1 \text { or } 2 \text { doses } \\
(0,28 \text { days }) ; \mathrm{IM}\end{array}$ & $\begin{array}{l}\text { Phase } 1 \\
\text { NA }\end{array}$ & $\begin{array}{l}\text { Humans } \\
\text { (90 partici- } \\
\text { pants) }\end{array}$ & {$[19,36]$} \\
\hline $\begin{array}{l}\text { Others } \\
\text { (VLP) }\end{array}$ & $\begin{array}{c}\text { Medicago Inc. } \\
\text { (July 2020-December 2021) }\end{array}$ & $\begin{array}{l}\text { Plant-derived VLP } \\
\text { adjuvanted with GSK } \\
\text { or Dynavax adjs. } \\
\text { NCT04450004 }\end{array}$ & $\begin{array}{c}3.75 \mu \mathrm{g}, 7.5 \mu \mathrm{g} \text { and } \\
15 \mu \mathrm{g} / \text { dose }\end{array}$ & $\stackrel{2}{2}(0,21$ days $) ; \mathrm{IM}$ & $\begin{array}{l}\text { Phase } 1 \\
\text { NA }\end{array}$ & $\begin{array}{l}\text { Humans } \\
\text { (180 partici- } \\
\text { pants, } \\
\text { Active-not } \\
\text { recruiting)) }\end{array}$ & {$[19,37]$} \\
\hline
\end{tabular}

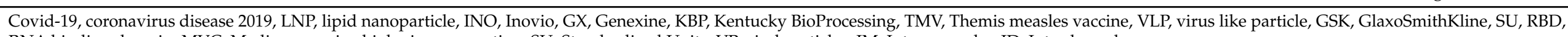
RNA binding domain, MVC, Medigen vaccine biologics corporation, SU, Standardized Units, VP, viral particles, IM, Intramuscular, ID, Intradermal. 


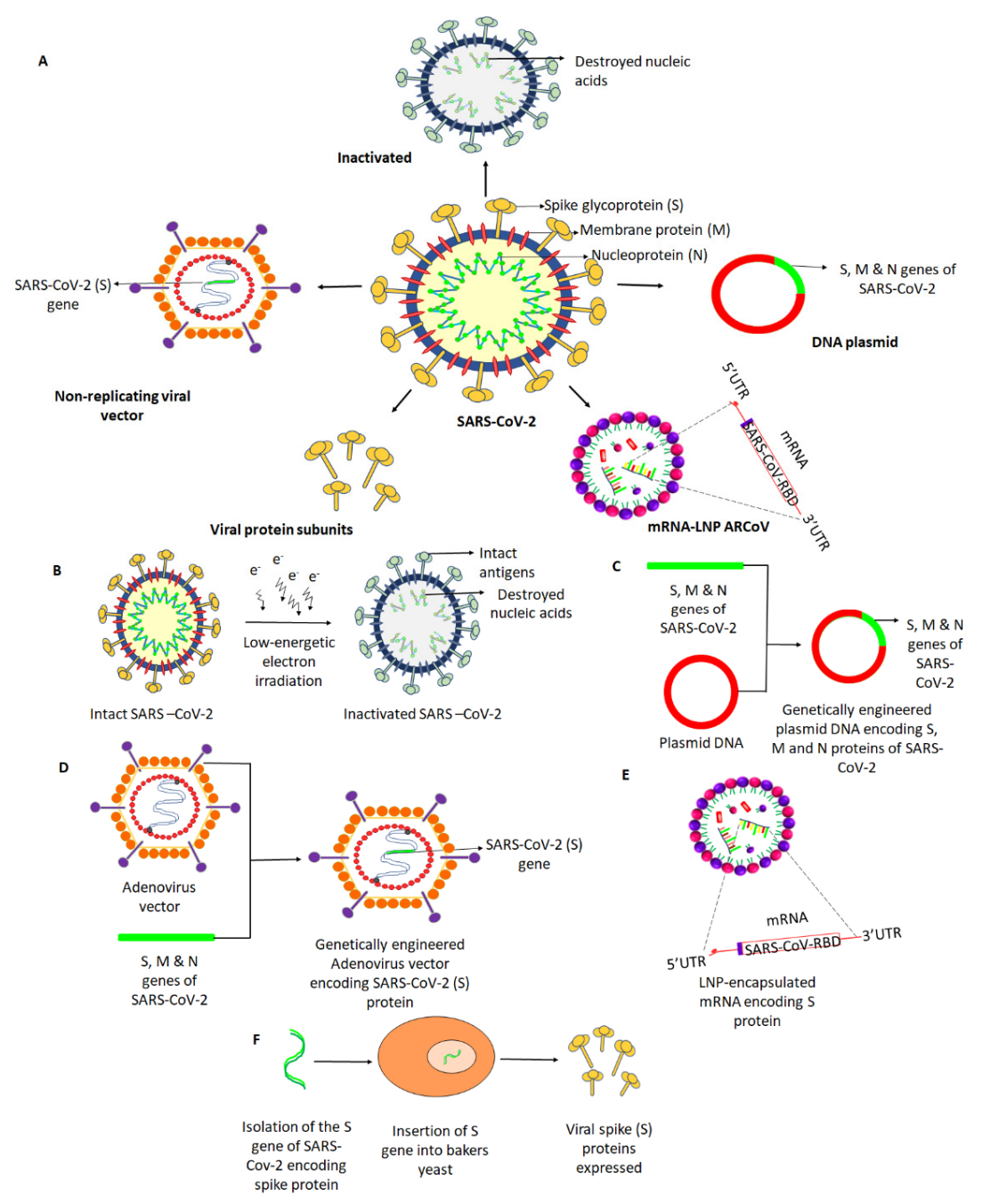

Figure 1. Different approaches for the development of vaccine candidates against SARS-Cov-2. (A) Potential vaccines under development involve five leading platforms (inactivated virus, protein subunit, DNA, RNA, and non-replicating viral vector), as depicted. (B) Intact SARS-CoV-2 is neutralized by treatment with radiation to cease its ability to infect and replicate, while preserving the induction of an immune response. (C) A plasmid DNA is genetically engineered with the $S$, $M$, and $N$ genes of SARS-CoV-2 encoding the respective proteins that may facilitate an immune response. (D) A replication-defective Adenovirus (Ad) vector is genetically engineered to express SARS-Cov-2 spike (S) protein. (E) An mRNA (replication-defective) that encodes the S protein of SARS-CoV-2 is encapsulated in a lipid nanoparticle (LNP), which, when injected, induces the body cells to produce the spike protein and direct the immune response. (F) Spike protein-encoding (S) gene of SARS-CoV-2 was isolated and genetically engineered into a baker's yeast, producing the spike protein antigens when grown. The produced $S$ antigens can then be collected and purified.

\subsection{Inactivated Viral Vaccine}

An inactivated vaccine (whole killed virus) consists of virus particles whose replication has ceased but that retain the ability to induce an immune response [38]. Inactivated vaccines are synthesized by neutralizing a virus using heat radiation or chemicals such as $\beta$-propriolactone (Figure 1B). Inactivated vaccines can be produced at a large scale with reduced effort compared to other viral vaccines and would induce a robust immune response if used with proper adjuvants [38]. PiCoVacc (NCT04456595) is an inactivated virus vaccine developed by the Beijing-based Sinovac Biotech [39]. According to the investigators, this vaccine elicits neutralizing antibodies and could stimulate a ten-fold increase in antibodies against the virus's spike protein in mice, rats, and macaques $[27,40]$. 
Concerning safety, it did not cause fever and weight loss; both appetite and mental state remained stable in the tested animals after immunization with PiCoVacc [27].

Moreover, histopathological evaluations of various organs, including lung, heart, spleen, liver, kidney, and brain from the tested animals demonstrated that PiCoVacc did not cause any notable pathology, especially in macaques [27]. Sinovac (Sinopharm) began Phase I and Phase II trials in April. The participants did not report any adverse effects in early clinical trials. The researchers found that the vaccine triggered neutralizing antibodies 14 days following vaccination with double dosage at day zero and 14 . As of now, recruiting procedures have been started for a Phase III clinical trial with an estimated study completion date by October 2021 [39,41]. Besides, before the completion of the Phase III trial, Sinovac biotech has received emergency-use approval of this vaccine under a program in China to vaccinate high-risk groups and prevent possible new outbreaks. In this complete analysis of Phase I and Phase II clinical trials recently, Sinopharm also developed an inactivated form of the SARS-CoV-2 candidate vaccine (ChiCTR2000034780) and published its clinical trial data recently [40]. The researchers found that the vaccine elicited neutralizing antibodies while inducing mild pain at the injection site and fever in a small subset of vaccinated subjects [42]. Given these data, the company has already begun its clinical Phase III trials with expected completion by July 2021 [43].

\subsection{Non-Replicating Viral Vector}

Non-replicating viral vaccine platforms use primarily replication-defective viral vectors. These are based on a weakened common cold virus that readily infects human cells but is incapable of causing disease. Adenoviruses (Ad) are among the most heavily exploited non-replicating vectors that mimic a natural viral infection and induce the production of the target viral proteins inside host cells (Figure 1C) [44]. Adenovirus vectorbased strategies are being developed to prevent or control an emerging infectious disease. Ad vector vaccines were developed against human immunodeficiency virus (HIV), ebola, and influenza and are under clinical evaluation [45]. To date, there is no Ad vector-based vaccine approved officially for human use. This platform's limitations include pre-existing neutralizing antibodies against the vector, induction of inflammatory responses, sequestering of the vector in the liver and spleen, and immunodominance of the vector genes over transgenes [46]. As of recently, adenovirus type-5-vectored coronavirus (Ad5-nCov) (ChiCTR2000030906) against SARS-Cov-2 is the first vector-based vaccine in a Phase III clinical trial, developed by the Beijing Institute of Biotechnology and CanSino Biologics. This genetically engineered vaccine candidate acts as a vector for the expression of the SARS-CoV-2 spike protein that has been shown to induce a good immune response with protective efficacy [21]. Furthermore, the data of Phase I and Phase II analyses, indicated mild to moderate adverse events among the participants, and further investigation will be continued until 31 January 2021 [47]. In collaboration with Oxford University, the pharmaceutical company AstraZeneca is developing another non-replicating viral vaccine named ChAdOx1 nCoV-19 (NCT04324606.), also known as the Oxford vaccine [48]. The ChAdOx1 nCoV-19 vaccine consists of the replication-deficient simian adenovirus vector ChAdOx1, containing the full-length spike protein of SARS-CoV-2, with a tissue plasminogen activator leader sequence [6]. As per the preliminary findings, the candidate vaccine appears safe, tolerated, and induced high levels of neutralizing antibodies in the participants. Further, the study reported no serious adverse events related to ChAdOx1 nCoV-19 [6]. As of now, the study is in a Phase III clinical trial, with an expected release date by October 2021. Johnson \& Johnson's Janssen experimental COVID-19 vaccine (NCT04436276) is another vaccine based on a non-replicating adenoviral vector. The vaccine uses adenovirus serotype 26 (Ad26) to expresses the SARS-CoV-2 spike protein. The results from its experimentation in non-human primates (NHP) have recently been published [49]. Of note, the study demonstrated robust single-shot vaccine protection against SARS-CoV-2, with nearly a complete protective efficacy and optimal neutralizing antibody responses [49]. As of now, it is currently being evaluated in Phase I and IIa clinical trials, with an expected completion 
date by November 2023 [50]. Gam-COVID-Vac Lyo (NCT04437875, renamed Sputnik V) is another non-replicating-vector-based vaccine with a combination of two adenoviruses, Ad5 and Ad26, both engineered with the spike gene. It is developed by the Gamaleya Research Institute, and its Phase III trials were recently launched [51]. However, there are no reports on the effective dose, immune response, and efficacy from Phase I or Phase II trials against COVID-19 [52]. The study has started recruiting participants for a Phase III trial, with a very close completion date estimated in August 2020 [52].

\subsection{RNA Vaccine}

mRNA vaccines are new-generation vaccination strategies effective in activating the immune response in a way similar to that of natural infection. They are short synthetic viral mRNAs, used by the host to produce the target antigens. Further, the mRNA used in the vaccine is reportedly safe, as it cannot integrate into the host genome (Figure 1D). One such mRNA vaccine candidate is mRNA-1273 (NCT04283461), developed by Moderna, a Massachusetts-based biotechnology company [53]. This vaccine is synthesized using non-replicating RNA genetic material in a lipid nanoparticle (LNP) formulation, which encodes a prefusion-stabilized form of the spike protein of SARS-CoV-2 [31]. The vaccine directs the body cells to express the spike protein in its prefusion conformation to elicit an immune response. The study data indicate that this vaccine is well tolerated and prompted neutralizing antibody activity in healthy adults [31]. Regarding its safety, more than half of the participants reported fatigue, headache, chills, myalgia, or pain at the injection site, but no serious adverse effects were reported. Likewise, mild to moderate symptoms were reported among older adults in a recent report published by the NCT04283461 trial group [32]. Given these data, the company is forging on with a Phase IIa trial, with a target completion date by August 2021 [31]. BioNTech, in partnership with Pfizer and Fosun Pharma, proposed a vaccine candidate in two versions: BNT162b1, which encodes a secreted trimerized SARS-CoV-2 receptor-binding domain, and BNT162b2, which encodes a prefusion-stabilized membrane-anchored SARS-CoV-2 full-length spike [54]. Interim safety and immunogenicity data collected from Phase I clinical trials of BNT162b1 in younger adults had been reported earlier from the US and Germany, while BNT162b2 was associated with less systemic reactogenicity, especially in older adults [30]. At present, after Phase IIb and III trials of BNT162b2, an upcoming large clinical trial will focus on checking long-term immunity, with an expected release date by November 2022 [54]. Another mRNA vaccine candidate is ARCoV (Chictr2000034112), currently in its Phase III clinical trial, with expected release date in December 2022. The vaccine was proposed jointly by the Academy of Military Sciences, Suzhou Abogen Biosciences, and Walvax Biotechnology Company. The trial data indicated that the ARCoV vaccine induced high levels of neutralizing antibodies in mice and crab-eating macaques and induced protective $\mathrm{T}$ cell immune responses [55]. Moreover, the immune response to the spike protein's receptor-binding domain will be explored [56].

\subsection{DNA-Based Vaccine}

DNA vaccination provides attractive approaches compared to viral vector-based, live vaccines due to DNA vaccine stability, simplicity, efficacy, and safety. DNA vaccines consist of plasmid DNA encoding antigenic viral proteins known to induce both B and T cell responses. In the field of DNA vaccination, substantial progress has been achieved concerning vaccine safety and efficacy [57]. The fundamental idea behind DNA vaccines is to induce immune responses against recombinant antigens encoded by genetically engineered DNA plasmids (Figure 1E). After immunization, the host cellular machinery facilitates the expression of plasmid-encoded genes, which leads to the generation of foreign antigens that can be processed and presented by both major histocompatibility complex (MHC) class I and II molecules. The immune system can recognize these host-synthesized foreign antigens, inducing a complete and adequate immunization [48]. INO-4800 is one such DNA vaccine currently in clinical trial. 
Further, the INO-4800 vaccine targets the major surface antigen spike protein of the SARS-CoV-2 virus and is known to generate a robust binding and neutralizing antibody response in guinea pigs and mice [29]. The vaccine is introduced in the human body by a hand-held smart device called CELECTRA ${ }^{\circledR}$, which uses a brief electrical pulse to reversibly open small pores in the cells to allow the plasmids to enter [58]. The study also detected these antibodies in the lungs of the vaccinated animals, which could be important in the protection against SARS-CoV-2. Another DNA vaccine, GX-19 (NTC04445389), administered via electroporation, is being developed by a Genexine-led consortium, the International Vaccine Institute, GenNbio, Korea Advanced Institute of Science and Technology, and Pohang University of Science and Technology. In view of a clinical study, initial experiments found a robust production of antibodies in mice and NHP models capable of neutralizing the novel CoV-2. Moreover, the adverse effects of vaccination and antigen-specific $\mathrm{T}$ cell immune response need to be assessed using various doses of GX-19; the proposed completion date is by June 2022 [59].

\subsection{Protein Subunit}

A protein subunit (adjuvanted recombinant vaccine) vaccine is based on antigens/viral components that best stimulate the human immune system without introducing viral particles (Figure 1F) [38]. It requires the insertion of adjuvants to elicit a protective immune response, because the antigen alone is incapable of inducing long-term immunity [60]. Based on the $S$ protein, protein subunit vaccines are likely to activate antibodies that prevent virus binding and later fusion of membranes, thereby counteracting virus infection [6] China's Chongqing Zhifei Biological products developed a protein subunit recombinant protein vaccine (NCT04466085) that is into Phase II human trials. However, the investigators did not provide details of the outcome of the Phase I test of the experimental vaccine and have proposed a study completion date by December 2021 [61].

Within the context of global health, our knowledge about health challenges posed by pathogens potentially causing infectious disease epidemics and pandemics has increased. These challenges inspired efforts to curtail SARS-CoV-2 spread by developing vaccines. As of now, different platforms are widely used for vaccine development. These platforms have their advantages and disadvantages, with respect to vaccines ability to induce an effective immune response, manufacturing capacity, and users' safety (Table 2). The viral vector-based vaccine technology employs either live (replicating but often attenuated) or non-replicating vectors. Viral vector-based vaccines could induce an immune response to the target antigen. Viral genomes can be manipulated to express an antigen of choice, enhancing their ability to accept relatively more insertions in the genome, and can be used to develop vaccines against various pathogens.

Additionally, viral vector vaccines could be delivered without added adjuvants and, depending on which vector is employed, antigen-specific cellular and humoral immune responses could be induced. High production has been achieved for commonly employed viral-based vaccines, supporting these technologies for pandemic settings [62]. However, so far, only one viral vector-based vaccine has been approved for use in humans. Dengvaxia is a recombinant Dengue vaccine based on yellow fever attenuated strain 17D, recently approved to prevent Dengue in previously infected individuals [62]. Further, several clinical trials have been done using viral vector-based vaccines, like that with vesicular stomatitis virus-Zaire ebolavirus (VSV-ZEBOV) — that has been shown to induce a protective response in humans [62]. Adenoviral vectors have many advantages. They are used to deliver genes in vivo, as most human cells express primary adenovirus receptors and secondary integrin receptors [63]. They are commonly used vectors in clinical trials globally and are being employed in more than $20 \%$ of all gene therapy trials. They allow the application of viral capsid modification strategies to increase their therapeutic characteristics and enhance virus targeting specificity [63]. AdVs are used to deliver engineered CRISPR/Cas9 systems to target cells and or tissues for genome engineering $[64,65]$, which could not be achieved effectively through other viral systems. 
Table 2. Different vaccine platforms-pros and cons and examples of licensed non-SARS-CoV-2 vaccines for humans.

\begin{tabular}{|c|c|c|c|c|}
\hline Vaccine Platform & Advantages & Disadvantages & $\begin{array}{l}\text { Examples of Licensed Viral Vaccines } \\
\text { Targeted for Humans }\end{array}$ & References \\
\hline Viral vector-based & $\begin{array}{l}\text { Exhibit highly specific gene delivery into the } \\
\text { host cell with rigorous immune response. } \\
\text { No infectious virus needs to be handled, shows } \\
\text { significant preclinical and clinical data for many } \\
\text { emerging viruses, including MERS-CoV. }\end{array}$ & $\begin{array}{l}\text { Host's immunity against the vector might } \\
\text { negatively affect the effectiveness of the } \\
\text { vaccine (depends on the vector chosen). } \\
\text { The integration of the viral genome into the } \\
\text { host genome may cause cancer. }\end{array}$ & $\begin{array}{ll}\text { - } & \text { JYNNEOS (smallpox/Monkeypox) } \\
\text { - } & \text { ACAM2000 (smallpox) } \\
\text { Adenovirus type } 4 \text { and type } 7 \\
\\
\text { vaccine, live, oral (febrile acute } \\
\text { respiratory) } \\
\text { - } \\
\text { Dengvaxia (Dengue) }\end{array}$ & {$[16,66-68]$} \\
\hline
\end{tabular}

- $\quad$ Develops long-lasting immunity

Live attenuated

High potency and pre-existing infrastructure used for several licensed human vaccines.

- $\quad$ Low-cost manufacturing.
- Possible regression to virulence strain.

- $\quad$ Limited use in immunocompromised patients.

- Making infectious clones for attenuated coronavirus vaccine seed may be time consuming because of its large genome size.

- Extensive safety testing required
- $\quad$ ERVEBO (Ebola virus)

- $\quad$ MMR II (Measles, Mumps and Rubella)
- $\quad$ Stable and safe compared to live attenuated virus platform.

- $\quad$ Pre-existing technology and infrastructure

Inactivated required for development are available.

- Can be used in immunocompromised patients

- Has already been tested in humans for various diseases such as SARS-CoV-1 and adjuvants can be used to increase immunogenicity.
- Requires booster doses to maintain immunity.

Large amount of virus needs to be handled and antigen integrity needs to be confirmed.

- Low production titer.
- $\quad$ Poliovax (Polio)

- $\quad$ Flucelvax Quadrivalent (Influenza)

- Ixiaro (Japanese Encephalitis)

- Imovax (Rabies)
- Handling of infectious viral particle is not required.

RNA
- Low-cost and ease of manufacturing.

- Translation of mRNA occurs in the cytosol of

the host cell thus reducing the risk of integration into the host genome.
- May have low immunogenicity due to instability.

- Safety issue with reactogenicity have been reported for various RNA based vaccines.

- Multiple doses may be required. 
Table 2. Cont.

\begin{tabular}{|c|c|c|c|c|}
\hline Vaccine Platform & Advantages & Disadvantages & $\begin{array}{c}\text { Examples of Licensed Viral Vaccines } \\
\text { Targeted for Humans }\end{array}$ & References \\
\hline DNA & $\begin{array}{l}\text { - Handling of infectious viral particle is not } \\
\text { required. } \\
\text { - } \quad \text { Tase of manufacturing. } \\
\text { cold-chain free }\end{array}$ & $\begin{array}{l}\text { - The titer remains low, even though it elicits } \\
\text { both cytotoxic and humoral immunity. } \\
\text { Potential integration to human genome } \\
\text { causes abnormalities. }\end{array}$ & None & {$[16,66-68]$} \\
\hline Protein subunit & $\begin{array}{l}\text { - Can be used in immunocompromised patients. } \\
\text { Does not involve any live component of the } \\
\text { viral particle }\end{array}$ & $\begin{array}{l}\text { - } \quad \text { Low immunogenicity. } \\
\text { - Conjugation leads to batch-wise variation. }\end{array}$ & $\begin{array}{l}\text { - } \quad \text { PedvaxHIB (Haemophilus influenzae } \\
\text { type b) } \\
\text { - } \quad \text { Engerix-B (Hepatitis B) } \\
\text { - } \quad \text { Recombivax HB (hepatitis B) }\end{array}$ & {$[16,66-68]$} \\
\hline
\end{tabular}

MERS-CoV, Middle East respiratory syndrome coronavirus, SARS-CoV, severe acute respiratory syndrome-corona virus. 
Moreover, high-capacity adenoviral vectors (HC-AdVs) could deliver anti-PD1/PDL1 immune checkpoint therapeutics for cancer treatment [69,70]. However, they also present challenges. The main obstacles to using viral vectors are immune system reactions, the vector packaging capacity, viral longevity, and viral contamination with helper virus (HV). Viral components removal and the emergence of high-capacity adenoviral vectors (HC-AdVs) considerably decreased the immune reaction, among other benefits. Immune reduction supports the prolongation of virus lifespan and prevents tissue damage and inflammation. A challenge related to HC-AdV prolonged expression is related to possible prior immunization against Ad. To overcome this concern, HC-AdV longevity could be optimized by encoding novel tetracycline-dependent (TetOn) regulatory elements [71]. With their expression regulated by doxycycline, HC-Ad-TetOn vectors showed better regulation and effectiveness than constitutively active $\mathrm{HC}-\mathrm{AdV}$, in the presence of an immune response [72]. The deficiency of specific viral genes enhanced the packaging capacity. However, the presence of the viral packaging machinery could pose challenges, as it limits the number of unique enzyme sites for transgene insertion. This concern was resolved using HD-AdVs with a unique transgene insertion site and preserving tissue specificity [73]. Moreover, viral-vectored vaccines require different manufacturing facilities and cellular systems, depending on the used virus. During synthesis, viruses might experience recombination, so precautionary measures need to be followed to keep cell cultures free of material leading to the emergence of recombined and uncharacterized pathogens [74]. More challenges are cellular barriers, viral targeting, and transport.

DNA-based vaccines have several advantages associated with their development and production. Nevertheless, they also have some disadvantages. One concern is the longterm persistence of DNA plasmids in host cells. Different preclinical studies demonstrated the existence of plasmid DNA for up to two years upon intramuscular injection, with lower but detectable expression and immunogenicity in a mouse model [75]. Additionally, the injection of bacterial DNA, sensed due to unmethylated CpG motifs, is linked with safety concerns, such as antibody generation against the injected DNA. Nonetheless, anti-DNA antibodies have not been detected in mice, rabbits, rats, or NHP [76]. Furthermore, cytokines or co-stimulatory molecules used to increase DNA immunogenicity could lead to unintended adverse effects by triggering cytokine expression and inducing generalized immune suppression, autoimmunity, or chronic inflammation. DNA vaccines have undergone clinical trials against a wide range of human pathogens like HIV, malaria, influenza virus, hepatitis $B$ virus, herpes simplex virus, and respiratory syncytial virus.

As of now, no DNA-based vaccine is licensed for human use. However, different DNA-based vaccines have been licensed for veterinary applications, such as the equine vaccine against West Nile Virus. Due to their incredible versatility, these vaccines have been tested for their efficacy against recent pandemic threats, including Ebola, Zika (ZIKV), and MERS [76]. The first vaccine for the Ebola virus was DNA-based [77]. It promoted the expression of a viral glycoprotein (GP) to induce neutralizing antibodies as well as nucleoprotein as an antibody target and inducer of $\mathrm{T}$ cell responses. Based on preclinical results using the DNA vaccine, a Phase I (NCT00072605) clinical trial for the DNA-based Ebola vaccine was started in 2003 [78]. The study employed a trivalent DNA vaccine comprising plasmids encoding transmembrane deleted forms of a glycoprotein derived from two Ebola viruses and a nucleoprotein generated by Vical Inc [78]. The study confirmed safety, tolerability, and a specific antibody response to at least one of the three viral antigens in all subjects. However, the virus-neutralizing response was not detected in this trial. Another clinical trial in Phase I (NCT00605514) started in 2008-2009 and showed an elicited response to transmembrane deletions of a viral GP in the context of adenoviral delivery in NHPs $[79,80]$.

Another clinical study in phase IB of two DNA vaccines that encode glycoproteins of Ebola virus and Marburg virus (MARV) demonstrated the safety of both vaccines [81]. An elicited immune response against a viral glycoprotein was observed in $80 \%$ of the subjects tested in the Phase IB study (NCT00997607) conducted in Uganda to establish the 
safety profile [81]. These vaccines were well tolerated, but the immune response to the Ebola virus and MARV was elicited in $50 \%$ and $30 \%$ of the subjects, respectively. Inovio developed a DNA vaccine for Ebola named INO-4212 (NCT02464670) and evaluated its efficacy and safety in a Phase I trial [82]. The study showed that $90 \%$ of the participants produced Ebola-specific antibodies [82].

Preclinical and clinical studies were also conducted to assess DNA vaccine protection ability against influenza viruses. Vaccines depend on the expression of plasmid-based hemagglutinin (HA), a viral surface glycoprotein and the main target of neutralizing antibodies against the influenza virus. In 2007, Phase I clinical trials of the DNA vaccine (NCT00709800 and NCT00694213) together with the lipid-based adjuvant Vaxfectin were conducted against influenza following the demonstration of its protective efficacy in mice and ferrets [83]. The vaccine was well tolerated and induced hemagglutination inhibition (HI) titers (a surrogate marker of neutralizing antibodies) of $\geq 40$; protection was elicited in $67 \%$ and $20 \%$ of HA-only and trivalent groups, respectively [84].

With the emergence of the Zika virus (ZIKV) in 2016, once again, DNA-based vaccines were considered highly desirable and reached clinical trials. The first approach developed by Inovio employed precursor membrane and envelope (prM-E) proteins from Asian, African, and American strains modified to comprise an IgE signal peptide along with the removal of putative glycosylation sites [85]. The results showed an immunogenic and protective effect of this vaccine in a mouse model upon intramuscular vaccination followed by electroporation [62]. Likewise, virus antibodies, as well as $\mathrm{T}$ cell response, were observed in NHP. Two Phase I clinical studies were initiated based on these data, one in flavivirusnaive individuals (NCT02809443) and the second one in dengue virus-seropositive subjects (NCT02887482). Preliminary results from this study demonstrated that the vaccine induced neutralizing antibodies and was well tolerated in $62 \%$ of the participants [62].

The use of RNA-based vaccine technologies in humans is less well characterized in comparison to that of DNA-based or viral vector-based vaccines [62]. Vaccines based on self-amplifying mRNA encode different influenza antigens mixed with LNPs or oil-inwater cationic nanoemulsions (CNE) showed immunogenicity in ferrets. They facilitated viral replication in the upper respiratory tract because of influenza infection and protected against the virus in mice $[86,87]$. Likewise, a mouse model has demonstrated that the RNA replicon of modified dendrimer nanoparticles (MDNP) provides protection against influenza and Ebola infections. Moreover, it showed antibody production and CD8 ${ }^{+} \mathrm{T}$ cell response against Zika virus [88,89]. However, efficacy, stability, and tolerance of selfamplifying mRNA vaccines are not evident in humans. Numerous preclinical studies have shown that non-replicating mRNA vaccines could induce an immune response and safeguard against pathogens, such as EBOV, influenza, and ZIKV [62]. Studies have shown that a single low-dose of intradermal (ID) immunization with LNP (lipid nanoparticle)encapsulated modified mRNA, encoding ZIKV prM-E glycoproteins, elicited neutralizing antibodies that showed protection in mice and NHPs $[90,91]$. Another study demonstrated that IM immunization with the same ZIKV vaccine showed enhanced titers of protective neutralizing antibodies and sterilizing immunity in mice [92,93]. LNP-encapsulated modified mRNA Ebola virus vaccine, encoding Ebola virus glycoprotein (EBOV GP), delivered IM (Intramuscular), demonstrated stimulated EBOV-specific IgG, neutralizing antibody response, and protection of guinea pigs from infection [94]. Further studies have shown that mRNA-based vaccines can elicit a protective immune response against influenza. Moreover, it was determined that ID intradermal-administered protamine complexed with a non-replicating sequence-optimized mRNA vaccine, encoding influenza HA, showed protection in mice against influenza H1N1, H3N2, and H5N1 and immunogenicity in ferrets and pigs [95]. Moreover, Phase-I clinical trials of H7N9 and H10N8 mRNA IM vaccines have shown no adverse effects. These mRNA vaccines have shown tolerance, protection, and elicited immunogenicity against H7N9 and H10N8 [96]. Table 3 reports a list of non-SARS-CoV-2 viral vaccine candidates in clinical development. 
Table 3. Non-SARS-CoV-2 viral vaccine candidates in clinical development.

\begin{tabular}{|c|c|c|c|}
\hline Study Start & Vaccine and Delivery & Study Outcomes & Reference \\
\hline $\begin{array}{l}\text { NCT00072605 } \\
\text { October } 2003\end{array}$ & $\begin{array}{l}\text { Ebola-DNA } \\
\text { trivalent; NF inj.dev.IM } 2-8 \mathrm{mg} \text { in week } 0,4 \text {, and } 8 \text { Antigens: } \\
\text { - } \quad \text { GP } \triangle \text { TM EBOV } \\
\text { - } \quad \text { GP } \triangle \text { TM SUDV } \\
\text { NP }\end{array}$ & $\begin{array}{l}\text { Phase I } \\
\text { - } \quad \text { Acceptable safety profile } \\
\text { - } \quad \text { Specific antibody response to at least } 1 / 3 \text { antigens in all subjects. } \\
\text { - } \quad \text { Specific } C D 8^{+} \text {T cell response in } 30 \% \text { subjects. } \\
\text { - } \quad \text { No detectable virus neutralizing responses. }\end{array}$ & \multirow{3}{*}[62,79,97]{} \\
\hline $\begin{array}{l}\text { NCT00605514 } \\
\text { January } 2008\end{array}$ & $\begin{array}{l}\text { Ebola-DNA } \\
\text { Mono or bivalent; NF inj.dev. IM } \\
4 \text { mg in week 0, 4, } 8 \text { Antigen: } \\
\text { - } \quad \text { GP MARV } \\
\text { - } \quad \text { GP EBOV + GP SUDV }\end{array}$ & $\begin{array}{l}\text { Phase I } \\
\text { - } \quad \text { Acceptable safety profile. } \\
\text { - Specific antibody responses against one of the GP's at week } 12 \text { in } 80 \% \text { of } \\
\text { subjects. } \\
\text { - } \quad \mathrm{CD}^{+} \mathrm{T} \text { cell response in some of the subjects. }\end{array}$ & \\
\hline $\begin{array}{l}\text { NCT02464670 } \\
\text { May } 2015\end{array}$ & $\begin{array}{l}\text { Ebola-DNA } \\
\text { mono-, bi-, or trivalent; IM or ID + EP in } 2 \text { or } 3 \text { doses } 0.8-4 \mathrm{mg} \mathrm{GP} ; 0.2-1 \mathrm{mg} \\
\text { IL } 12 \text { Antigen: } \\
\text { - } \quad \text { GP EBOV pre } 2013 \\
\text { - } \quad \text { and/or GP EBOV } 2014 \\
\text { and IL } 12 \text { in trivalent vaccine }\end{array}$ & $\begin{array}{l}\text { Phase I } \\
\text { - } \quad \text { Acceptable safety profile } \\
\text { - } \quad \text { Specific antibody responses in } 88 \% \text { (IM) and 95\% (ID) of participants. }\end{array}$ & \\
\hline $\begin{array}{l}\text { NCT00709800 and } \\
\text { NCT00694213 } \\
\text { August } 2007\end{array}$ & $\begin{array}{l}\text { Influenza H5N1-DNA } \\
\text { mono- or trivalent; needle or NF inj.dev. IM } 0.1-1 \text { mg in week } 0,3 \\
\text { Antigen: } \\
\text { - HA of/Vietnam/1203/04 } \\
\text { - } \quad \mathrm{HA}+\mathrm{NP}+\mathrm{M} 2\end{array}$ & $\begin{array}{l}\text { Phase I } \\
\text { - } \quad \text { Acceptable safety profile } \\
\text { - } \quad \text { Hi titers } \geq 40 \text {, in } 47-67 \% \text { (HA only) and } 0-20 \%(\mathrm{HA}+\mathrm{NP}+\mathrm{M} 2) \text { of } \\
\text { - } \quad \text { Responses against HA unaffected by injection method. }\end{array}$ & {$[62,98]$} \\
\hline $\begin{array}{l}\text { NCT00973895 } \\
\text { August } 2009\end{array}$ & $\begin{array}{l}\text { Influenza H1N1-DNA } \\
\text { Monovalent; NF inj.dev. IM } 4 \text { mg in week 0,4,8 } \\
\text { Antigen: } \\
\text { - HA of A/California/04/2009 }\end{array}$ & $\begin{array}{l}\text { Phase I } \\
\text { - } \quad \text { Acceptable safety profile } \\
\text { - } \quad \text { HI titers } \geq 40 \text { in } 30 \% \text { of DNA vaccinated subjects } \\
\text { - } \quad \text { DNA + licensed vaccine HI titers } \geq 40 \text { in } 72 \% \\
\text { - } \quad \text { T cell response in } 25 \% \text { of subjects }\end{array}$ & {$[62,99]$} \\
\hline
\end{tabular}


Table 3. Cont.

\begin{tabular}{lll}
\hline Study Start & Vaccine and Delivery & Study Outcomes \\
\hline & & Phase I \\
NCT02809443 & Zika-DNAmonovalent; ID + EP 1 or 2 mg in week 0,4,12 Antigen: & $\bullet \quad$ VNTs in 62\% of the participants (Vero cell assay) \\
July 2016 & Consensus prM-E; IgE SP; removed glycosylation site & $\bullet \quad \begin{array}{l}\text { Protection of 92\% of mice by passive serum transfer in challenge mode } \\
\text { (IFN } \alpha / \beta \text { receptor knockout) }\end{array}$
\end{tabular}

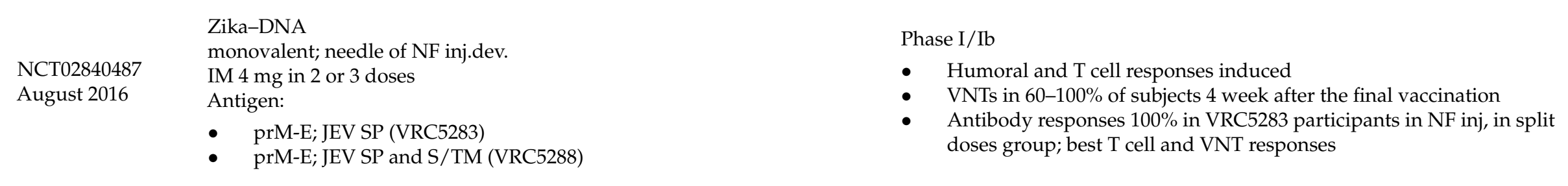

NCT03014089

December 2016

Zika-RNA

mRNA 1325, modified nucleotides; LNP formulated, Antigen: prM-E polyprotein

Phase I/II

\section{Influenza H10N8-RNA \\ mRNA 1851, modified nucleotides; LNP formulated, Antigen: \\ HA of H10N8 A/Jiangxi-Donghu/346/2013 \\ NCT03076385 \\ December 2016}

Phase I

\section{Influenza H7N9-RNA}

NCT03345043

mRNA 1440, modified nucleotides; LNP formulated, Antigen:

May 2016

HA of H7N9 A/Anhui/1/2013

- $\quad$ HI titers $\geq 40$ in $100 \%$ subjects at day 43

- $\mathrm{MN} \geq 20$ in $87 \%$ at day 43

Phase I

- $\quad$ Results pending

\section{NCT02344407}

October

2014-November

2015
Ebola-viral vector (non-replicating)

Single dose IM $2.5 \times 10^{10}, 5 \times 10^{10}$,

$1 \times 10^{11}$ VP Antigen: GP EBOV (1976)
- Serious adverse events within 12 months after inj. in 8.0\% $(40 / 500)$ of participants $(9.4 \%$ in rVSV-ZEBOV.

- Antibody responses in 70.8 and $63.5 \%$ of the participants at 1 and

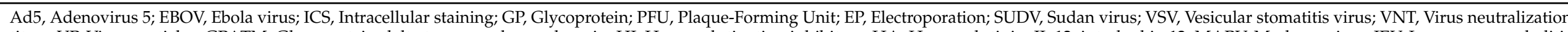

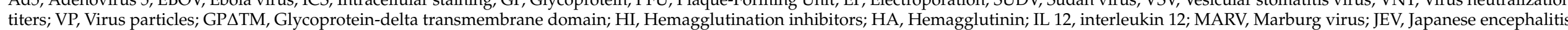

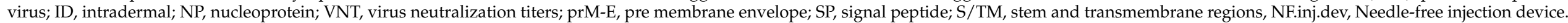




\section{Previous Vaccine Development for $\mathrm{CoV}$}

SARS-CoV and MERS-CoV emerged in 2002-2003 and 2012-2013, respectively, causing acute respiratory tract infections in humans [100]. Although different platforms of vaccine development (live-attenuated, inactivated, vector-based, protein subunit-based, and nucleic acid-based) were evaluated for SARS-CoV and MERS-CoV, no vaccine has been approved. Several studies showed cellular immune response against a SARS-CoV live attenuated vaccine [101-104]. However, the use of live attenuated vaccines carries the risk of virus reversal to its wild type or virulent forms, especially in immune-compromised individuals [105-107]. Moreover, a few studies showed lung and liver inflammation, pro-inflammatory cytokine secretion, and neutrophil influx in animal models $[108,109]$. These vaccines are also not appropriate for an immunologically sensitive population, as they need multiple and high dosages, might allow virus reversal to its virulent form, or might induce a suboptimal response.

Compared to live attenuated vaccines, inactivated (non-replicating) vaccines are considered a safer option [110]. A formaldehyde-inactivated SARS-CoV vaccine adjuvanted with aluminum hydroxide preserved antigenicity, eliciting neutralizing antibodies in mice [111]. Another study showed that a UV-inactivated SARS-CoV vaccine elicited an immunogenic humoral response in mice. Further studies indicated humoral as well as mucosal immunity against an inactivated SARS-CoV vaccine in rhesus monkey [111]. However, the unpredictable immune response is one of the primary constraints of the inactivated vaccine [110]. Few studies have shown that inactivated vaccines are associated with adverse events, like inflammation, lung lesions, eosinophil infiltration, and weak or delayed immune response [111,112].

Several protein subunit-based vaccines were developed against the influenza virus, meningitis, hepatitis B, and pneumonia [113-116]. Studies have considered full-length or segmented coronavirus proteins for vaccines, such as the receptor-binding domain or full-length spike or envelop proteins [113-118]. A study showed that a fusion of protein containing spike protein residues $318-510$ produced an efficient immune response in rabbits [119]. Another study showed that SARS-CoV S2 epitope peptide elicited antigenicity of the S2 protein [115]. Moreover, a MERS-CoV vaccine based on the receptor-binding domain demonstrated both humoral and cellular responses with the least dose of the antigen $(1 \mu \mathrm{g})$ [120]. Protein subunit-based vaccines have the least chances of adverse effects. Since they lead to the production of a short antigen segment, they are safe compared to live attenuated and inactivated vaccines [113]. On the other hand, some reports showed inadequate or delayed immunogenic response against SARS-CoV because of lack of viral genetic material, but this could be overcome using a suitable adjuvant $[114,116,118]$.

Nucleic acid-based vaccine are safe compared to live attenuated and inactivated vaccines [121,122]. One study showed that the SARS-CoV conserved nucleocapsid protein induced the production of $\mathrm{CD}^{+}$cytotoxic T lymphocytes and $\gamma$-interferon response [123]. Another study demonstrated that the injection of fragments of the SARS-CoV spike gene resulted in the production of cytotoxic $\mathrm{T}$ lymphocytes, IgG, and CD8 $8^{+} \mathrm{T}$ lymphocytes in rats between 3 and 7 weeks from the injection [124]. Likewise, a study has shown that $T$ helper type-1 and type- 2 immune responses against SARS-CoV were induced as a result of the combining DNA killed-virus vaccines [125]. Another DNA vaccine was designed to encode the S1 and S2 subunits and induced an immune response (a specific antibody) in mice [126]. The drawbacks were a limited immune response linked the specific or engineered genetic material, laborious genetic engineering, injection site pain, and required adjuvant for long-term immunity [124,127].

\section{Target Groups to Receive Vaccines}

Targeted immunization approaches are designed to increase the immunization level of populations prone to severe health conditions. Considering this, priorities related to the administration of COVID-19 vaccination are critical and must be decided in society's best interest. The U.S. Centers for Disease Control and Prevention (CDC) has made a five-tier 
scheme of vaccination. The top tier includes critical healthcare and other workers [128]. Tiers two and three comprise people working in healthcare and having other essential jobs or those who are 65 years and older, live in long-term care facilities, or have medical conditions with an increased risk of developing COVID-19. Tier four and five include the general population. In addition, prisoners, meat packers, soldiers, and grocery store workers also need to be considered as their professions or environment dramatically increase their risk of being infected [128]. Studies have shown that pregnant women might be at increased risk for severe COVID-19 and should be given priority [129]. Therefore, timeliness of targeted immunization will ensure saving lives, protecting the healthcare system, and finally restoring the suffering global economy.

\section{Conclusions}

People around the world are facing one of the biggest challenges of their lives, trying to protect themselves against COVID-19. The pandemic has inadvertently affected the lives of people, health and education systems, and the economy. Vaccination remains the mainstay for mitigating the pandemic and restoring some normalcy in the world. Prior efforts in vaccine development (live attenuated, inactivated, vector-based, protein subunit-based, and nucleic acid-based), targeting other viruses, including MERS and SARS, have facilitated the development of a vaccine for COVID-19. Vaccination for COVID-19 may be essential to achieve herd immunity and limit virus spread. However, concerns arise regarding vaccine reactogenicity and long-term side effects. Although the progress is fast thanks to the scientific community's robust efforts, the production of a safe, effective, and preventive vaccine to control the COVID-19 pandemic might take a few more months.

Author Contributions: Conceptualization, H.M.Y. and H.Z.; methodology, S.M.; software, M.F.; validation, H.M.Y., H.Z. and S.M.; formal analysis, M.F.; investigation, S.M.; resources, M.F.; data curation, N.A.H.; writing-original draft preparation, M.F.; writing-review and editing, H.Z.; visualization, N.A.H.; supervision, H.M.Y.; project administration, A.A.A.T.; funding acquisition, F.M.B. All authors have read and agreed to the published version of the manuscript.

Funding: This research was supported by Qatar University Internal Grant No. \# QUHI-BRC-20/21-1. The findings achieved herein are solely the responsibility of the authors.

Conflicts of Interest: The authors declare no conflict of interest.

\section{References}

1. Zhu, N.; Zhang, D.; Wang, W.; Li, X.; Yang, B.; Song, J.; Zhao, X.; Huang, B.; Shi, W.; Lu, R.; et al. A Novel Coronavirus from Patients with Pneumonia in China, 2019. N. Engl. J. Med. 2020, 382, 727-733. [CrossRef] [PubMed]

2. Yang, W.; Sirajuddin, A.; Zhang, X.; Liu, G.; Teng, Z.; Zhao, S.; Lu, M. The role of imaging in 2019 novel coronavirus pneumonia (COVID-19). Eur. Radiol. 2020, 30, 1-9. [CrossRef] [PubMed]

3. Chen, Y.; Liu, Q.; Guo, D. Emerging coronaviruses: Genome structure, replication, and pathogenesis. J. Med. Virol. 2020, 92, 418-423. [CrossRef] [PubMed]

4. Arshad Ali, S.; Baloch, M.; Ahmed, N.; Arshad Ali, A.; Iqbal, A. The outbreak of Coronavirus Disease 2019 (COVID-19)-An emerging global health threat. J. Infect. Public Health 2020, 13, 644-646. [CrossRef] [PubMed]

5. Shang, J.; Wan, Y.; Luo, C.; Ye, G.; Geng, Q.; Auerbach, A.; Li, F. Cell entry mechanisms of SARS-CoV-2. Proc. Natl. Acad. Sci. USA 2020, 117, 11727-11734. [CrossRef] [PubMed]

6. Zhang, H.; Penninger, J.M.; Li, Y.; Zhong, N.; Slutsky, A.S. Angiotensin-converting enzyme 2 (ACE2) as a SARS-CoV-2 receptor: Molecular mechanisms and potential therapeutic target. Intensive Care Med. 2020, 46, 586-590. [CrossRef]

7. Ahluwalia, P.; Ahluwalia, M.; Vaibhav, K.; Mondal, A.; Sahajpal, N.; Islam, S.; Fulzele, S.; Kota, V.; Dhandapani, K.; Baban, B.; et al. Infections of the lung: A predictive, preventive and personalized perspective through the lens of evolution, the emergence of SARS-CoV-2 and its pathogenesis. EPMA J. 2020, 11, 581-601. [CrossRef]

8. Li, F.; Berardi, M.; Li, W.; Farzan, M.; Dormitzer, P.R.; Harrison, S.C. Conformational states of the severe acute respiratory syndrome coronavirus spike protein ectodomain. J. Virol. 2006, 80, 6794-6800. [CrossRef]

9. Zhu, Z.; Lian, X.; Su, X.; Wu, W.; Marraro, G.A.; Zeng, Y. From SARS and MERS to COVID-19: A brief summary and comparison of severe acute respiratory infections caused by three highly pathogenic human coronaviruses. Respir. Res. 2020, 21, 224. [CrossRef]

10. Duan, L.; Zheng, Q.; Zhang, H.; Niu, Y.; Lou, Y.; Wang, H. The SARS-CoV-2 Spike Glycoprotein Biosynthesis, Structure, Function, and Antigenicity: Implications for the Design of Spike-Based Vaccine Immunogens. Front. Immunol. 2020, 11, 576622. [CrossRef] 
11. Naming the Coronavirus Disease (COVID-19) and the Virus That Causes It. Available online: https://www.who.int/ emergencies / diseases / novel-coronavirus-2019/technical-guidance/naming-the-coronavirus-disease-(covid-2019)-and-thevirus-that-causes-it (accessed on 8 September 2020).

12. Zheng, J. SARS-CoV-2: An Emerging Coronavirus that Causes a Global Threat. Int. J. Biol. Sci. 2020, 16, 1678-1685. [CrossRef] [PubMed]

13. Petrosillo, N.; Viceconte, G.; Ergonul, O.; Ippolito, G.; Petersen, E. COVID-19, SARS and MERS: Are they closely related? Clin. Microbiol. Infect. 2020, 26, 729-734. [CrossRef] [PubMed]

14. Cucinotta, D.; Vanelli, M. WHO declares COVID-19 a pandemic. Acta Bio Med. Atenei Parm. 2020, 91, 157-160.

15. Menzella, F.; Biava, M.; Barbieri, C.; Livrieri, F.; Facciolongo, N. Pharmacologicaltreatment of COVID-19: Lights and shadows. Drugs Context 2020, 9, 4-6. [CrossRef]

16. Amanat, F.; Krammer, F. SARS-CoV-2 Vaccines: Status Report. Immunity 2020, 52, 583-589. [CrossRef] [PubMed]

17. Ahn, D.G.; Shin, H.J.; Kim, M.H.; Lee, S.; Kim, H.S.; Myoung, J.; Kim, B.T.; Kim, S.J. Current Status of Epidemiology, Diagnosis, Therapeutics, and Vaccines for Novel Coronavirus Disease 2019 (COVID-19). J. Microbiol. Biotechnol. 2020, 30, 313-324. [CrossRef]

18. Chen, W.H.; Strych, U.; Hotez, P.J.; Bottazzi, M.E. The SARS-CoV-2 Vaccine Pipeline: An Overview. Curr. Trop. Med. Rep. 2020, 7 , 61-64. [CrossRef]

19. Draft Landscape of COVID-19 Candidate Vaccines. Available online: https://www.who.int/publications/m/item/draftlandscape-of-covid-19-candidate-vaccines (accessed on 8 September 2020).

20. Accelerating a Safe and Effective COVID-19 Vaccine. Available online: https://www.who.int/emergencies/diseases/ novel-coronavirus-2019/global-research-on-novel-coronavirus-2019-ncov/accelerating-a-safe-and-effective-covid-19-vaccine (accessed on 8 September 2020).

21. Zhu, F.C.; Li, Y.H.; Guan, X.H.; Hou, L.H.; Wang, W.J.; Li, J.X.; Wu, S.P.; Wang, B.S.; Wang, Z.; Wang, L.; et al. Safety, tolerability, and immunogenicity of a recombinant adenovirus type- 5 vectored COVID-19 vaccine: A dose-escalation, open-label, nonrandomised, first-in-human trial. Lancet 2020, 395, 1845-1854. [CrossRef]

22. Logunov, D.Y.; Dolzhikova, I.V.; Zubkova, O.V.; Tukhvatullin, A.I.; Shcheblyakov, D.V.; Dzharullaeva, A.S.; Grousova, D.M.; Erokhova, A.S.; Kovyrshina, A.V.; Botikov, A.G.; et al. Safety and immunogenicity of an rAd26 and rAd5 vector-based heterologous prime-boost COVID-19 vaccine in two formulations: Two open, non-randomised phase $1 / 2$ studies from Russia. Lancet 2020, 396, 887-897. [CrossRef]

23. Zhu, F.C.; Guan, X.H.; Li, Y.H.; Huang, J.Y.; Jiang, T.; Hou, L.H.; Li, J.X.; Yang, B.F.; Wang, L.; Wang, W.J.; et al. Immunogenicity and safety of a recombinant adenovirus type-5-vectored COVID-19 vaccine in healthy adults aged 18 years or older: A randomised, double-blind, placebo-controlled, phase 2 trial. Lancet 2020, 396, 479-488. [CrossRef]

24. Graham, S.P.; McLean, R.K.; Spencer, A.J.; Belij-Rammerstorfer, S.; Wright, D.; Ulaszewska, M.; Edwards, J.C.; Hayes, J.W.P.; Martini, V.; Thakur, N.; et al. Evaluation of the immunogenicity of prime-boost vaccination with the replication-deficient viral vectored COVID-19 vaccine candidate ChAdOx1 nCoV-19. NPJ Vaccines 2020, 5, 69. [CrossRef] [PubMed]

25. Oxford Coronavirus Vaccine Produces Strong Immune Response in Older Adults. Available online: https://www.research. ox.ac.uk/Article/2020-11-19-oxford-coronavirus-vaccine-produces-strong-immune-response-in-older-adults (accessed on 20 November 2020).

26. Palacios, R.; Patiño, E.G.; de Oliveira Piorelli, R.; Conde, M.; Batista, A.P.; Zeng, G.; Xin, Q.; Kallas, E.G.; Flores, J.; Ockenhouse, C.F.; et al. Double-Blind, Randomized, Placebo-Controlled Phase III Clinical Trial to Evaluate the Efficacy and Safety of treating Healthcare Professionals with the Adsorbed COVID-19 (Inactivated) Vaccine Manufactured by Sinovac-PROFISCOV: A structured summary of a study protocol for a randomised controlled trial. Trials 2020, 21, 853. [PubMed]

27. Gao, Q.; Bao, L.; Mao, H.; Wang, L.; Xu, K.; Yang, M.; Li, Y.; Zhu, L.; Wang, N.; Lv, Z.; et al. Development of an inactivated vaccine candidate for SARS-CoV-2. Science 2020, 369, 77-81. [CrossRef]

28. Xia, S.; Duan, K.; Zhang, Y.; Zhao, D.; Zhang, H.; Xie, Z.; Li, X.; Peng, C.; Zhang, Y.; Zhang, W.; et al. Effect of an Inactivated Vaccine Against SARS-CoV-2 on Safety and Immunogenicity Outcomes: Interim Analysis of 2 Randomized Clinical Trials. JAMA 2020, 324, 951-960. [CrossRef] [PubMed]

29. Smith, T.R.F.; Patel, A.; Ramos, S.; Elwood, D.; Zhu, X.; Yan, J.; Gary, E.N.; Walker, S.N.; Schultheis, K.; Purwar, M.; et al. Immunogenicity of a DNA vaccine candidate for COVID-19. Nat. Commun. 2020, 11, 2601. [CrossRef]

30. Walsh, E.E.; Frenck, R.; Falsey, A.R.; Kitchin, N.; Absalon, J.; Gurtman, A.; Lockhart, S.; Neuzil, K.; Mulligan, M.J.; Bailey, R.; et al. RNA-Based COVID-19 Vaccine BNT162b2 Selected for a Pivotal Efficacy Study. medRxiv 2020. [CrossRef]

31. Jackson, L.A.; Anderson, E.J.; Rouphael, N.G.; Roberts, P.C.; Makhene, M.; Coler, R.N.; McCullough, M.P.; Chappell, J.D.; Denison, M.R.; Stevens, L.J.; et al. An mRNA Vaccine against SARS-CoV-2-Preliminary Report. N. Engl. J. Med. 2020, 383, $1920-1931$. [CrossRef]

32. Anderson, E.J.; Rouphael, N.G.; Widge, A.T.; Jackson, L.A.; Roberts, P.C.; Makhene, M.; Chappell, J.D.; Denison, M.R.; Stevens, L.J.; Pruijssers, A.J.; et al. Safety and Immunogenicity of SARS-CoV-2 mRNA-1273 Vaccine in Older Adults. N. Engl. J. Med. 2020. [CrossRef]

33. Keech, C.; Albert, G.; Cho, I.; Robertson, A.; Reed, P.; Neal, S.; Plested, J.S.; Zhu, M.; Cloney-Clark, S.; Zhou, H.; et al. Phase 1-2 Trial of a SARS-CoV-2 Recombinant Spike Protein Nanoparticle Vaccine. N. Engl. J. Med. 2020, 383, 2320-2332. [CrossRef] 
34. Kuo, T.Y.; Lin, M.Y.; Coffman, R.L.; Campbell, J.D.; Traquina, P.; Lin, Y.J.; Liu, L.T.; Cheng, J.; Wu, Y.C.; Wu, C.C.; et al. Development of CpG-adjuvanted stable prefusion SARS-CoV-2 spike antigen as a subunit vaccine against COVID-19. Sci. Rep. 2020, 10, 20085. [CrossRef]

35. Qi, X.; Ke, B.; Feng, Q.; Yang, D.; Lian, Q.; Li, Z.; Lu, L.; Ke, C.; Liu, Z.; Liao, G. Construction and immunogenic studies of a $\mathrm{mFc}$ fusion receptor binding domain (RBD) of spike protein as a subunit vaccine against SARS-CoV-2 infection. Chem. Commun. 2020, 56, 8683-8686. [CrossRef] [PubMed]

36. Hörner, C.; Schürmann, C.; Auste, A.; Ebenig, A.; Muraleedharan, S.; Herrmann, M.; Schnierle, B.; Mühlebach, M.D. A Highly Immunogenic Measles Virus-based Th1-biased COVID-19 Vaccine. bioRxiv 2020. [CrossRef]

37. Medicago. 2020. Available online: https://www.medicircle.in/medicago-gsk-dynavax-partners-first-plant-based-covid-vaccine (accessed on 8 September 2020).

38. Pandey, S.C.; Pande, V.; Sati, D.; Upreti, S.; Samant, M. Vaccination strategies to combat novel corona virus SARS-CoV-2. Life Sci. 2020, 256, 117956. [CrossRef] [PubMed]

39. Clinical Trials. Available online: clinicaltrials.gov (accessed on 8 September 2020).

40. Yu, P.; Qi, F.; Xu, Y.; Li, F.; Liu, P.; Liu, J.; Bao, L.; Deng, W.; Gao, H.; Xiang, Z.; et al. Age-related rhesus macaque models of COVID-19. Anim. Model. Exp. Med. 2020, 3, 93-97. [CrossRef] [PubMed]

41. Sinovac COVID-19 Vaccine Gets Emergency Use Approval in China. Available online: https://www.pharmaceutical-technology. com/news/sinovac-vaccine-emergency-use/ (accessed on 15 October 2020).

42. Coronavirus COVID-19 Vaccines. Available online: https:/ / relief.unboundmedicine.com/relief/view/Coronavirus-Guidelines/ 2355056/all/Coronavirus_COVID_19_Vaccines (accessed on 7 December 2020).

43. A Phase III Clinical Trial for Inactivated Novel Coronavirus Pneumonia (COVID-19) Vaccine (Vero Cells). Available online: http:/ / www.chictr.org.cn/showprojen.aspx?proj=56651 (accessed on 6 December 2020).

44. Du, L.; He, Y.; Zhou, Y.; Liu, S.; Zheng, B.J.; Jiang, S. The spike protein of SARS-CoV-A target for vaccine and therapeutic development. Nat. Rev. Microbiol. 2009, 7, 226-236. [CrossRef] [PubMed]

45. Parks, C.L.; Picker, L.J.; King, C.R. Development of replication-competent viral vectors for HIV vaccine delivery. Curr. Opin. HIV AIDS 2013, 8, 402-411. [CrossRef] [PubMed]

46. Adenoviral Vector-Based Vaccines and Gene Therapies:current Status and Future Prospects. Available online: https: //www.intechopen.com/books/adenoviruses/adenoviral-vector-based-vaccines-and-gene-therapies-current-status-andfuture-prospects (accessed on 8 September 2020).

47. A Randomized, Double-Blinded, Placebo-Controlled Phase II Clinical Trial for Recombinant Novel Coronavirus (2019nCOV) Vaccine (Adenovirus Vector). Available online: http:/ / www.chictr.org.cn/ showprojen.aspx?proj=52006 (accessed on 8 September 2020).

48. Flingai, S.; Czerwonko, M.; Goodman, J.; Kudchodkar, S.; Muthumani, K.; Weiner, D. Synthetic DNA Vaccines: Improved Vaccine Potency by Electroporation and Co-Delivered Genetic Adjuvants. Front. Immunol. 2013, 4. [CrossRef]

49. Mercado, N.B.; Zahn, R.; Wegmann, F.; Loos, C.; Chandrashekar, A.; Yu, J.; Liu, J.; Peter, L.; McMahan, K.; Tostanoski, L.H.; et al. Single-shot Ad26 vaccine protects against SARS-CoV-2 in rhesus macaques. Nature 2020, 586, 583-588. [CrossRef]

50. Study of Ad26.COV2.S in Adults (COVID-19). Available online: https: / / clinicaltrials.gov/ct2/ show /NCT04436276?term=NCT0 $4436276 \&$ draw $=2 \&$ rank $=1$ (accessed on 8 September 2020).

51. Callaway, E. Russia's fast-track coronavirus vaccine draws outrage over safety. Nature 2020, 584, 334. [CrossRef]

52. An Open Study of the Safety, Tolerability and Immunogenicity of 'Gam-COVID-Vac Lyo' Vaccine against COVID-19. Available online: https: / / www.smartpatients.com/trials / NCT04437875 (accessed on 8 September 2020).

53. Phase 1 Study of Investigational mRNA Vaccine for COVID-19 Underway. Available online: https://www.pulmonologyadvisor $\mathrm{com} /$ home/topics/lung-infection/phase-1-study-of-investigational-mrna-vaccine-for-covid-19-underway/ (accessed on 8 September 2020).

54. Study to Describe the Safety, Tolerability, Immunogenicity and Efficacy of RNA Vaccine Candidates against COVID-19 in Healthy Individuals. Available online: https:/ / clinicaltrials.gov/ct2/show/NCT04368728 (accessed on 8 September 2020).

55. China's First COVID-19 mRNA Vaccine Approved for Clinical Trials. Available online: https://covid-19.chinadaily.com.cn/a/20 2006/30/WS5efb010da310834817256345.html (accessed on 8 September 2020).

56. Chinese Clinical Trial Registry. A Phase I Clinical Trial to Evaluate the Safety, Tolerance and Preliminary Immunogenicity of Different Doses of a SARS-CoV-2 mRNA Vaccine in Population Aged 18-59 Years and 60 Years and Above. 2020. Available online: http:/ / www.chictr.org.cn/ showprojen.aspx?proj=55524 (accessed on 8 September 2020).

57. MacGregor, R.R.; Boyer, J.D.; Ugen, K.E.; Lacy, K.E.; Gluckman, S.J.; Bagarazzi, M.L.; Chattergoon, M.A.; Baine, Y.; Higgins, T.J.; Ciccarelli, R.B. First human trial of a DNA-based vaccine for treatment of human immunodeficiency virus type 1 infection: Safety and host response. J. Infect. Dis. 1998, 178, 92-100. [CrossRef]

58. INO-4800 DNA Coronavirus Vaccine. Available online: https://www.myendnoteweb.com/EndNoteWeb.html?func= downloadInstallers\&cat=download\& (accessed on 9 September 2020).

59. GX-19 Clinical Trials. Safety and Immunogenicity Study of GX-19, a COVID-19 Preventive DNA Vaccine in Healthy Adults. 2020. Available online: https:/ / clinicaltrials.gov/ct2/show / NCT04445389?term=vaccine\&cond=covid-19\&draw $=3$ (accessed on 10 September 2020).

60. Vaccine Types. Available online: https://www.niaid.nih.gov/research/vaccine-types (accessed on 8 September 2020). 
61. Clinical Study of Recombinant Novel Coronavirus Vaccine. Available online: https:/ clinicaltrials.gov/ct2/show / NCT0446608 5 ?term $=$ NCT04466085\&draw $=2 \&$ rank=1 (accessed on 10 September 2020).

62. Rauch, S.; Jasny, E.; Schmidt, K.E.; Petsch, B. New Vaccine Technologies to Combat Outbreak Situations. Front. Immunol. 2018, 9, 1963. [CrossRef] [PubMed]

63. Crystal, R.G. Adenovirus: The first effective in vivo gene delivery vector. Hum. Gene. Ther. 2014, 25, 3-11. [CrossRef] [PubMed]

64. Hsu, P.D.; Lander, E.S.; Zhang, F. Development and applications of CRISPR-Cas9 for genome engineering. Cell 2014, 157, 1262-1278. [CrossRef] [PubMed]

65. Sternberg, S.H.; Doudna, J.A. Expanding the Biologist's Toolkit with CRISPR-Cas9. Mol. Cell 2015, 58, 568-574. [CrossRef]

66. Kaur, S.P.; Gupta, V. COVID-19 Vaccine: A comprehensive status report. Virus Res. 2020, 288, 198114. [CrossRef]

67. Ng, W.H.; Liu, X.; Mahalingam, S. Development of vaccines for SARS-CoV-2. F1000Research 2020, 9, 991. [CrossRef]

68. van Riel, D.; de Wit, E. Next-generation vaccine platforms for COVID-19. Nat. Mater. 2020, 19, 810-812. [CrossRef]

69. Khalil, D.N.; Smith, E.L.; Brentjens, R.J.; Wolchok, J.D. The future of cancer treatment: Immunomodulation, CARs and combination immunotherapy. Nat. Rev. Clin. Oncol. 2016, 13, 273-290. [CrossRef]

70. Figueroa, J.A.; Reidy, A.; Mirandola, L.; Trotter, K.; Suvorava, N.; Figueroa, A.; Konala, V.; Aulakh, A.; Littlefield, L.; Grizzi, F.; et al. Chimeric antigen receptor engineering: A right step in the evolution of adoptive cellular immunotherapy. Int. Rev. Immunol. 2015, 34, 154-187. [CrossRef]

71. Xiong, W.; Goverdhana, S.; Sciascia, S.A.; Candolfi, M.; Zirger, J.M.; Barcia, C.; Curtin, J.F.; King, G.D.; Jaita, G.; Liu, C.; et al. Regulatable gutless adenovirus vectors sustain inducible transgene expression in the brain in the presence of an immune response against adenoviruses. J. Virol. 2006, 80, 27-37. [CrossRef]

72. Xiong, W.; Candolfi, M.; Kroeger, K.M.; Puntel, M.; Mondkar, S.; Larocque, D.; Liu, C.; Curtin, J.F.; Palmer, D.; Ng, P.; et al. Immunization against the transgene but not the TetON switch reduces expression from gutless adenoviral vectors in the brain. Mol. Ther. 2008, 16, 343-351. [CrossRef] [PubMed]

73. Shi, C.-X.; Graham, F.L.; Hitt, M.M. A convenient plasmid system for construction of helper-dependent adenoviral vectors and its application for analysis of the breast-cancer-specific mammaglobin promoter. J. Gene Med. 2006, 8, 442-451. [CrossRef] [PubMed]

74. Condit, R.C.; Williamson, A.-L.; Sheets, R.; Seligman, S.J.; Monath, T.P.; Excler, J.-L.; Gurwith, M.; Bok, K.; Robertson, J.S.; Kim, D.; et al. Unique safety issues associated with virus-vectored vaccines: Potential for and theoretical consequences of recombination with wild type virus strains. Vaccine 2016, 34, 6610-6616. [CrossRef] [PubMed]

75. Armengol, G.; Ruiz, L.M.; Orduz, S. The injection of plasmid DNA in mouse muscle results in lifelong persistence of DNA, gene expression, and humoral response. Mol. Biotechnol. 2004, 27, 109-118. [CrossRef]

76. Schalk, J.A.; Mooi, F.R.; Berbers, G.A.; van Aerts, L.A.; Ovelgönne, H.; Kimman, T.G. Preclinical and clinical safety studies on DNA vaccines. Hum. Vaccin. 2006, 2, 45-53. [CrossRef]

77. Dolzhikova, I.V.; Tokarskaya, E.A.; Dzharullaeva, A.S.; Tukhvatulin, A.I.; Shcheblyakov, D.V.; Voronina, O.L.; Syromyatnikova, S.I.; Borisevich, S.V.; Pantyukhov, V.B.; Babira, V.F.; et al. Virus-Vectored Ebola Vaccines. Acta Nat. 2017, 9, 4-11. [CrossRef]

78. Experimental Ebola Vaccine Trial. Available online: https://clinicaltrials.gov/ct2/show/NCT00072605 (accessed on 15 October 2020).

79. Sarwar, U.N.; Costner, P.; Enama, M.E.; Berkowitz, N.; Hu, Z.; Hendel, C.S.; Sitar, S.; Plummer, S.; Mulangu, S.; Bailer, R.T.; et al. Safety and immunogenicity of DNA vaccines encoding Ebolavirus and Marburgvirus wild-type glycoproteins in a phase I clinical trial. J. Infect. Dis. 2015, 211, 549-557. [CrossRef]

80. Sullivan, N.J.; Geisbert, T.W.; Geisbert, J.B.; Shedlock, D.J.; Xu, L.; Lamoreaux, L.; Custers, J.H.H.V.; Popernack, P.M.; Yang, Z.-Y.; Pau, M.G.; et al. Immune Protection of Nonhuman Primates against Ebola Virus with Single Low-Dose Adenovirus Vectors Encoding Modified GPs. PLoS Med. 2006, 3, e177. [CrossRef]

81. Kibuuka, H.; Berkowitz, N.M.; Millard, M.; Enama, M.E.; Tindikahwa, A.; Sekiziyivu, A.B.; Costner, P.; Sitar, S.; Glover, D.; $\mathrm{Hu}, \mathrm{Z}$; ; et al. Safety and immunogenicity of Ebola virus and Marburg virus glycoprotein DNA vaccines assessed separately and concomitantly in healthy Ugandan adults: A phase 1b, randomised, double-blind, placebo-controlled clinical trial. Lancet 2015, 385, 1545-1554. [CrossRef]

82. Open-Label Study of INO-4212 with or without INO-9012. Administered IM or ID Followed by Electroporation in Healthy Volunteers. Available online: https:/ / clinicaltrials.gov/ct2/show /NCT02464670 (accessed on 9 September 2020).

83. Lalor, P.A.; Webby, R.J.; Morrow, J.; Rusalov, D.; Kaslow, D.C.; Rolland, A.; Smith, L.R. Plasmid DNA-Based Vaccines Protect Mice and Ferrets against Lethal Challenge with A/Vietnam/1203/04 (H5N1) Influenza Virus. J. Infect. Dis. 2008, 197, 1643-1652. [CrossRef]

84. Lee, L.Y.Y.; Izzard, L.; Hurt, A.C. A Review of DNA Vaccines against Influenza. Front. Immunol. 2018, 9, 1568. [CrossRef] [PubMed]

85. Muthumani, K.; Griffin, B.D.; Agarwal, S.; Kudchodkar, S.B.; Reuschel, E.L.; Choi, H.; Kraynyak, K.A.; Duperret, E.K.; Keaton, A.A.; Chung, C.; et al. In Vivo protection against ZIKV infection and pathogenesis through passive antibody transfer and active immunisation with a prMEnv DNA vaccine. Npj Vaccines 2016, 1, 16021. [CrossRef] [PubMed]

86. Brazzoli, M.; Magini, D.; Bonci, A.; Buccato, S.; Giovani, C.; Kratzer, R.; Zurli, V.; Mangiavacchi, S.; Casini, D.; Brito, L.M.; et al. Induction of Broad-Based Immunity and Protective Efficacy by Self-amplifying mRNA Vaccines Encoding Influenza Virus Hemagglutinin. J. Virol. 2016, 90, 332. [CrossRef] [PubMed] 
87. Hekele, A.; Bertholet, S.; Archer, J.; Gibson, D.; Palladino, G.; Brito, L.; Otten, G.; Brazzoli, M.; Buccato, S.; Bonci, A.; et al. Rapidly produced SAM (R) vaccine against H7N9 influenza is immunogenic in mice. Emerg. Microbes Infect. 2013, 2, 1-7. [CrossRef] [PubMed]

88. Chahal, J.S.; Fang, T.; Woodham, A.W.; Khan, O.F.; Ling, J.; Anderson, D.G.; Ploegh, H.L. An RNA nanoparticle vaccine against Zika virus elicits antibody and CD8+ T cell responses in a mouse model. Sci. Rep. 2017, 7, 252. [CrossRef]

89. Chahal, J.S.; Khan, O.F.; Cooper, C.L.; McPartlan, J.S.; Tsosie, J.K.; Tilley, L.D.; Sidik, S.M.; Lourido, S.; Langer, R.; Bavari, S.; et al. Dendrimer-RNA nanoparticles generate protective immunity against lethal Ebola, H1N1 influenza, and Toxoplasma gondii challenges with a single dose. Proc. Natl. Acad. Sci. USA 2016, 113, 4133-4142. [CrossRef]

90. Pardi, N.; Hogan, M.J.; Pelc, R.S.; Muramatsu, H.; Andersen, H.; DeMaso, C.R.; Dowd, K.A.; Sutherland, L.L.; Scearce, R.M.; Parks, R.; et al. Zika virus protection by a single low-dose nucleoside-modified mRNA vaccination. Nature 2017, 543, 248-251. [CrossRef]

91. Pardi, N.; Secreto, A.J.; Shan, X.; Debonera, F.; Glover, J.; Yi, Y.; Muramatsu, H.; Ni, H.; Mui, B.L.; Tam, Y.K.; et al. Administration of nucleoside-modified mRNA encoding broadly neutralizing antibody protects humanized mice from HIV-1 challenge. Nat. Commun. 2017, 8, 14630. [CrossRef]

92. Richner, J.M.; Jagger, B.W.; Shan, C.; Fontes, C.R.; Dowd, K.A.; Cao, B.; Himansu, S.; Caine, E.A.; Nunes, B.T.D.; Medeiros, D.B.A.; et al. Vaccine Mediated Protection Against Zika Virus-Induced Congenital Disease. Cell 2017, 170, 273-283. [CrossRef]

93. Richner, J.M.; Himansu, S.; Dowd, K.A.; Butler, S.L.; Salazar, V.; Fox, J.M.; Julander, J.G.; Tang, W.W.; Shresta, S.; Pierson, T.C.; et al. Modified mRNA Vaccines Protect against Zika Virus Infection. Cell 2017, 168, 1114-1125. [CrossRef]

94. Meyer, M.; Huang, E.; Yuzhakov, O.; Ramanathan, P.; Ciaramella, G.; Bukreyev, A. Modified mRNA-Based Vaccines Elicit Robust Immune Responses and Protect Guinea Pigs From Ebola Virus Disease. J. Infect. Dis. 2018, 217, 451-455. [CrossRef] [PubMed]

95. Petsch, B.; Schnee, M.; Vogel, A.B.; Lange, E.; Hoffmann, B.; Voss, D.; Schlake, T.; Thess, A.; Kallen, K.J.; Stitz, L.; et al. Protective efficacy of in vitro synthesized, specific mRNA vaccines against influenza A virus infection. Nat. Biotechnol. 2012, 30, 1210-1216. [CrossRef] [PubMed]

96. Feldman, R.A.; Fuhr, R.; Smolenov, I.; Ribeiro, A.; Panther, L.; Watson, M.; Senn, J.J.; Smith, M.; Almarsson, Ö.; Pujar, H.S.; et al. mRNA vaccines against H10N8 and H7N9 influenza viruses of pandemic potential are immunogenic and well tolerated in healthy adults in phase 1 randomized clinical trials. Vaccine 2019, 37, 3326-3334. [CrossRef]

97. Regules, J.A.; Beigel, J.H.; Paolino, K.M.; Voell, J.; Castellano, A.R.; Hu, Z.; Muñoz, P.; Moon, J.E.; Ruck, R.C.; Bennett, J.W.; et al. A Recombinant Vesicular Stomatitis Virus Ebola Vaccine. N. Engl. J. Med. 2017, 376, 330-341. [CrossRef] [PubMed]

98. Ledgerwood, J.E.; Bellamy, A.R.; Belshe, R.; Bernstein, D.I.; Edupuganti, S.; Patel, S.M.; Renehan, P.; Zajdowicz, T.; Schwartz, R.; Koup, R.; et al. DNA priming for seasonal influenza vaccine: A phase $1 \mathrm{~b}$ double-blind randomized clinical trial. PLoS ONE 2015, 10, e0125914. [CrossRef] [PubMed]

99. Crank, M.C.; Gordon, I.J.; Yamshchikov, G.V.; Sitar, S.; Hu, Z.; Enama, M.E.; Holman, L.A.; Bailer, R.T.; Pearce, M.B.; Koup, R.A.; et al. Phase 1 study of pandemic H1 DNA vaccine in healthy adults. PLoS ONE 2015, 10, e0123969. [CrossRef]

100. Kirtikumar, C.B.; Dipak, V.P.; Dipak, V.D.; Vikrant, P.P.; Ashish, B.B. COVID-19: A Review on Epidemiology, Clinical Features and Possible Potential Drugs Based on Available Case Studies. Coronaviruses 2020, 1, 1-17. [CrossRef]

101. Bukreyev, A.; Lamirande, E.W.; Buchholz, U.J.; Vogel, L.N.; Elkins, W.R.; St Claire, M.; Murphy, B.R.; Subbarao, K.; Collins, P.L. Mucosal immunisation of African green monkeys (Cercopithecus aethiops) with an attenuated parainfluenza virus expressing the SARS coronavirus spike protein for the prevention of SARS. Lancet 2004, 363, 2122-2127. [CrossRef]

102. Kapadia, S.U.; Rose, J.K.; Lamirande, E.; Vogel, L.; Subbarao, K.; Roberts, A. Long-term protection from SARS coronavirus infection conferred by a single immunization with an attenuated VSV-based vaccine. Virology 2005, 340, 174-182. [CrossRef]

103. Netland, J.; DeDiego, M.L.; Zhao, J.; Fett, C.; Álvarez, E.; Nieto-Torres, J.L.; Enjuanes, L.; Perlman, S. Immunization with an attenuated severe acute respiratory syndrome coronavirus deleted in E protein protects against lethal respiratory disease. Virology 2010, 399, 120-128. [CrossRef]

104. Graham, R.L.; Becker, M.M.; Eckerle, L.D.; Bolles, M.; Denison, M.R.; Baric, R.S. A live, impaired-fidelity coronavirus vaccine protects in an aged, immunocompromised mouse model of lethal disease. Nat. Med. 2012, 18, 1820-1826. [CrossRef] [PubMed]

105. Escriou, N.; Callendret, B.; Lorin, V.; Combredet, C.; Marianneau, P.; Février, M.; Tangy, F. Protection from SARS coronavirus conferred by live measles vaccine expressing the spike glycoprotein. Virology 2014, 452-453, 32-41. [CrossRef] [PubMed]

106. Menachery, V.D.; Gralinski, L.E.; Mitchell, H.D.; Dinnon, K.H., 3rd; Leist, S.R.; Yount, B.L., Jr.; McAnarney, E.T.; Graham, R.L.; Waters, K.M.; Baric, R.S. Combination Attenuation Offers Strategy for Live Attenuated Coronavirus Vaccines. J. Virol. 2018, 92, e007010-e007018. [CrossRef] [PubMed]

107. Jimenez, G.S.; Planchon, R.; Wei, Q.; Rusalov, D.; Geall, A.; Enas, J.; Lalor, P.; Leamy, V.; Vahle, R.; Luke, C.J.; et al. Vaxfectin ${ }^{\mathrm{TM}} \_$ Formulated Influenza DNA Vaccines Encoding NP and M2 Viral Proteins Protect Mice against Lethal Viral Challenge. Hum. Vaccines 2007, 3, 157-164. [CrossRef] [PubMed]

108. Regla-Nava, J.A.; Nieto-Torres, J.L.; Jimenez-Guardeño, J.M.; Fernandez-Delgado, R.; Fett, C.; Castaño-Rodríguez, C.; Perlman, S.; Enjuanes, L.; DeDiego, M.L. Severe acute respiratory syndrome coronaviruses with mutations in the E protein are attenuated and promising vaccine candidates. J. Virol. 2015, 89, 3870-3887. [CrossRef]

109. DeDiego, M.L.; Álvarez, E.; Almazán, F.; Rejas, M.T.; Lamirande, E.; Roberts, A.; Shieh, W.-J.; Zaki, S.R.; Subbarao, K.; Enjuanes, L. A Severe Acute Respiratory Syndrome Coronavirus That Lacks the E Gene Is Attenuated In Vitro and In Vivo. J. Virol. 2007, 81, 1701-1713. [CrossRef] 
110. Stauffer, F.; El-Bacha, T.; Da Poian, A.T. Advances in the development of inactivated virus vaccines. Pat. Anti Infect. Drug Discov. 2006, 1, 291-296. [CrossRef]

111. Zhang, C.H.; Lu, J.H.; Wang, Y.F.; Zheng, H.Y.; Xiong, S.; Zhang, M.Y.; Liu, X.J.; Li, J.X.; Wan, Z.Y.; Yan, X.G.; et al. Immune responses in Balb/c mice induced by a candidate SARS-CoV inactivated vaccine prepared from F69 strain. Vaccine 2005, 23, 3196-3201. [CrossRef]

112. Agrawal, A.S.; Tao, X.; Algaissi, A.; Garron, T.; Narayanan, K.; Peng, B.H.; Couch, R.B.; Tseng, C.T. Immunization with inactivated Middle East Respiratory Syndrome coronavirus vaccine leads to lung immunopathology on challenge with live virus. Hum. Vaccines Immunother. 2016, 12, 2351-2356. [CrossRef]

113. Vartak, A.; Sucheck, S. Recent Advances in Subunit Vaccine Carriers. Vaccines 2016, 4, 12. [CrossRef]

114. Guo, Y.; Sun, S.; Wang, K.; Zhang, S.; Zhu, W.; Chen, Z. Elicitation of immunity in mice after immunization with the S2 subunit of the severe acute respiratory syndrome coronavirus. DNA Cell Biol. 2005, 24, 510-515. [CrossRef] [PubMed]

115. Feng, Y.; Wan, M.; Wang, X.; Zhang, P.-Y.; Yong, Y.; Wang, L.-Y. Expression of predicted B cell epitope peptide in S2 subunit of SARS coronavirus spike protein in E.coli and identification of its mimic antigenicity. Xi bao Yu Fen Zi Mian Yi Xue Za Zhi Chin. J. Cell. Mol. Immunol. 2007, 23, 113-116.

116. Zakhartchouk, A.N.; Sharon, C.; Satkunarajah, M.; Auperin, T.; Viswanathan, S.; Mutwiri, G.; Petric, M.; See, R.H.; Brunham, R.C.; Finlay, B.B.; et al. Immunogenicity of a receptor-binding domain of SARS coronavirus spike protein in mice: Implications for a subunit vaccine. Vaccine 2007, 25, 136-143. [CrossRef] [PubMed]

117. Kalita, P.; Padhi, A.K.; Zhang, K.Y.J.; Tripathi, T. Design of a peptide-based subunit vaccine against novel coronavirus SARS-CoV-2. Microb. Pathog. 2020, 145, 104236. [CrossRef]

118. Kim, E.; Erdos, G.; Huang, S.; Kenniston, T.W.; Balmert, S.C.; Carey, C.D.; Raj, V.S.; Epperly, M.W.; Klimstra, W.B.; Haagmans, B.L.; et al. Microneedle array delivered recombinant coronavirus vaccines: Immunogenicity and rapid translational development. EBioMedicine 2020, 55, 102743. [CrossRef]

119. He, Y.; Zhou, Y.; Liu, S.; Kou, Z.; Li, W.; Farzan, M.; Jiang, S. Receptor-binding domain of SARS-CoV spike protein induces highly potent neutralizing antibodies: Implication for developing subunit vaccine. Biochem. Biophys Res. Commun. 2004, 324, 773-781. [CrossRef]

120. Tang, J.; Zhang, N.; Tao, X.; Zhao, G.; Guo, Y.; Tseng, C.T.; Jiang, S.; Du, L.; Zhou, Y. Optimization of antigen dose for a receptor-binding domain-based subunit vaccine against MERS coronavirus. Hum. Vaccines Immunother. 2015, 11, 1244-1250. [CrossRef]

121. Liu, M.A. DNA vaccines: An historical perspective and view to the future. Immunol. Rev. 2011, 239, 62-84. [CrossRef]

122. Dutta, N.K.; Mazumdar, K.; Lee, B.-H.; Baek, M.-W.; Kim, D.-J.; Na, Y.-R.; Park, S.-H.; Lee, H.-K.; Kariwa, H.; Mai, L.Q.; et al. Search for potential target site of nucleocapsid gene for the design of an epitope-based SARS DNA vaccine. Immunol. Lett. 2008, 118, 65-71. [CrossRef]

123. Zhao, P.; Cao, J.; Zhao, L.J.; Qin, Z.L.; Ke, J.S.; Pan, W.; Ren, H.; Yu, J.G.; Qi, Z.T. Immune responses against SARS-coronavirus nucleocapsid protein induced by DNA vaccine. Virology 2005, 331, 128-135. [CrossRef]

124. Li, J.; Qin, H.D.; Liu, P.; Zhang, J.W.; Feng, B.-J.; Feng, Q.S.; Chen, L.Z.; Pan, Z.G.; Huang, L.X.; Zhang, R.H.; et al. Immunogenicity of DNA vaccine that express spike gene fragment of SARS coronavirus. Chin. J. Microbiol. Immunol. 2005, 25, $297-301$.

125. Zakhartchouk, A.N.; Liu, Q.; Petric, M.; Babiuk, L.A. Augmentation of immune responses to SARS coronavirus by a combination of DNA and whole killed virus vaccines. Vaccine 2005, 23, 4385-4391. [CrossRef] [PubMed]

126. Wang, R.L.; Jin, N.Y.; Jin, H.T. Immune response induced by DNA vaccine encoding SARS-CoV S1 and S2 proteins in mice. Chin. J. Biol. 2007, 20, 426-428.

127. He, H.; Tang, Y.; Qin, X.; Xu, W.; Wang, Y.; Liu, X.; Xiong, S.; Li, J.; Zhang, M.; Duan, M. Construction of a eukaryotic expression plasmid encoding partial $S$ gene fragments of the SARS-CoV and its potential utility as a DNA vaccine. DNA Cell Biol. 2005, 24, 516-520. [CrossRef] [PubMed]

128. Cohen, J. The line starts to form for a coronavirus vaccine. Science 2020, 369, 15-16. [CrossRef]

129. Ellington, S.; Strid, P.; Tong, V.T.; Woodworth, K.; Galang, R.R.; Zambrano, L.D.; Nahabedian, J.; Anderson, K.; Gilboa, S.M. Characteristics of Women of Reproductive Age with Laboratory-Confirmed SARS-CoV-2 Infection by Pregnancy StatusUnited States, January 22-June 7, 2020. Morb. Mortal. Wkly. Rep. 2020, 69, 769-775. [CrossRef] 